\title{
HIGH CRIMES AND MISCONCEPTIONS: THE ICC AND NON-PARTY STATES
}

\author{
MADELINE MORRIS*
}

I

\section{INTRODUCTION}

The Rome Treaty for an International Criminal Court ("ICC") ${ }^{1}$ provides for the establishment of an international court with jurisdiction over genocide, war crimes, and crimes against humanity. ${ }^{2}$ Those crimes often are committed by or with the approval of governments. It is unlikely that a government sponsoring genocide, war crimes, or crimes against humanity would consent to the prosecution of its national for his or her participation. Therein lies the problem with an international criminal court that may exercise jurisdiction only if the defendant's state of nationality consents. The very states that are most likely to be implicated in serious international crimes are the least likely to grant jurisdiction over their nationals to an international court.

The ICC Treaty avoids the dismal prospect of an international criminal court that cannot obtain jurisdiction over international criminals. The treaty provides that the ICC may exercise jurisdiction even over nationals of states that are not parties to the Treaty and have not otherwise consented to the court's jurisdiction. Article 12 provides that, in addition to jurisdiction based on Security Council action under Chapter VII of the United Nations Charter and jurisdiction based on consent by the defendant's state of nationality, the ICC will have jurisdiction to prosecute the national of any state when crimes within the court's subject-matter jurisdiction are committed on the territory of a state that is a party to the treaty or that consents to ICC jurisdiction for that case. That territorial basis would empower the court to exercise jurisdiction even in

Copyright (C) 2001 by Madeline Morris

This article is also available at http://www.law.duke.edu/journals/64LCPMorris.

* Professor of Law, Duke University.

This article is a modified version of a chapter by the same title appearing in INTERNATIONAL CRimes, PEACE, AND Human Rights: THE Role of THE INTERNATIONAL CRIMINAl CourT (Dinah Shelton ed., 2000).

1. Rome Statute of the International Criminal Court, July 17, 1998, U.N. Doc. A/CONF. 183/9 [hereinafter ICC Treaty].

2. See id. art. 5. While the ICC Treaty also provides for jurisdiction over the crime of aggression, see $i d$. art. 5(1)(d), the treaty further provides that the ICC shall not exercise that part of its subjectmatter jurisdiction until such time as the treaty is amended to include provisions defining the crime of aggression and setting out the conditions under which the court will exercise jurisdiction over that crime. See id. art. 5(2). 
cases where the defendant's state of nationality is not a party to the treaty and does not consent to the exercise of jurisdiction. ${ }^{3}$

The United States has objected to the ICC Treaty on the ground that, by purporting to confer upon the court jurisdiction over the nationals of nonconsenting non-party states, the treaty would bind non-parties in contravention of the law of treaties. ${ }^{4}$ This objection has given rise to a heated controversy that has focused on the particulars of the international law of treaties and of jurisdiction. On close inspection, however, we can detect a more basic issue struggling to make its way to the surface.

The fundamental issue concerns the nature of the ICC as an international institution. The jurisdictional structure of the ICC is based on a view of the ICC as a criminal court, tout court. In this view, the job of the ICC is to adjudicate the guilt or innocence of individuals accused of recognized international crimes. With this model in mind, it makes sense to give the court meaningful powers of compulsory jurisdiction, lest perpetrators of serious international crimes should escape justice. From this perspective one might reason that, if the court's subject-matter jurisdiction is limited to established international crimes and the process of the court is fair, then no state-whether party or nonparty-should have legitimate objections to the court's exercise of jurisdiction over its nationals.

The deficiency of this approach is that it reflects only one of the two types of cases that the ICC will be called upon to decide. In addition to the cases that are concerned solely with individual culpability, there will be ICC cases that focus on the lawfulness of official acts of states. Even while individuals, and not states, will be named in ICC indictments, there will be cases in which those in-

3. Note, however, the gap in jurisdiction. If a crime is committed by a non-party national on that non-party's territory, then the ICC may not exercise jurisdiction. So, even if the ICC had existed at the relevant time, it would not, for example, have been able to exercise jurisdiciton over the crimes of Pol Pot in Cambodia or Kambanda in Rwanda if Cambodia or Rwanda, respectively, were non-parties to the ICC Treaty. In this way, the ICC's effectiveness as an enforcement mechanism is significantly limited.

See id. art. 12. Article 13(a) of the treaty articulates a third condition permitting the exercise of ICC jurisdiction. Even in the absence of the nationality or territoriality preconditions articulated in Article 12, the ICC may exercise jurisdiction if the case arises from a situation referred to the ICC prosecutor by the U.N. Security Council acting under Chapter VII of the U.N. Charter. See id. art. 13.

Where the defendant's state of nationality is a party to the ICC Treaty or specially consents to ICC jurisdiction for the case in question, the ICC's jurisdiction is founded on the consent of the state of nationality. Where ICC jurisdiction is based on Security Council action, the jurisdiction also arguably rests on the consent of the state of nationality (assuming that it is a U.N. member state) through its membership in the U.N., which entails consent to cooperate with Security Council actions taken under Chapter VII. See U.N. CHARTER art. 25. But see Brief for the Appellant, Prosecutor v. Tadic, International Tribunal for the former Yugoslavia, Case No. IT-94-1-AR72 (arguing that the Security Council is inherently incapable of legitimately establishing a judicial organ). The present article will focus not on these consent-based foundations for ICC jurisdiction but, rather, on the territorially based foundation which, by the terms of the treaty, allows the ICC to exercise jurisdiction over nationals of states that have not consented to its jurisdiction.

4. See David Scheffer, U.S. Ambassador at Large for War Crimes Issues, The International Criminal Court: The Challenge of Jurisdiction, Address at the Annual Meeting of the American Society of International Law (Mar. 26, 1999) (on file with author). 
dividuals are indicted for official acts taken pursuant to state policy and under state authority. These official-act cases may well include cases in which an official state act is characterized as criminal by the ICC prosecutor (acting, very possibly, on a referral from an aggrieved state), while the state whose national is being prosecuted maintains that the act was lawful. One can readily imagine ICC cases in which the act forming the basis for the indictment was a military intervention, deployment of a particular weapon, recourse to a certain method of warfare, or other official conduct that the responsible state maintains was lawful. Or the act forming the basis for the indictment might be an alleged official act that the concerned state maintains never occurred. In these sorts of ICC cases, notwithstanding the presence of individual defendants in the dock, the cases will represent bona fide legal disputes between states.

When the ICC is hearing cases in the official-acts category, its function will resemble less that of a municipal criminal court than that of an international court for the adjudication of interstate legal disputes. The shortcomings of the ICC jurisdictional structure and of the arguments that have been advanced in support of that structure stem from the fact that this second aspect of the ICC's character, that of a court for interstate dispute adjudication, is not adequately taken into account.

There is a range of mechanisms for the resolution of interstate disputes. Adjudication is among them, but is not always the approach best suited to a given dispute. Because in many circumstances states see diplomatic, nonadjudicatory dispute resolution as posing fewer risks and offering potentially more constructive resolutions than litigation would, states often are reluctant to submit their disputes to third-party adjudication. As we shall see, states are particularly unwilling to enter into broad commitments to adjudicate future disputes, the content and contours of which cannot be foreseen.

The interest of states in retaining discretion as to their methods of addressing interstate disputes is reflected in the jurisdictional structures of the International Court of Justice ("ICJ") and of specialized international courts of such as the Law of the Sea Tribunal and the World Trade Organization ("WTO") dispute settlement system. The constituting instruments of those international courts reserve to states broad discretion over whether and when those courts will have decisionmaking authority.

The drafters of the ICC Treaty faced the dilemma of needing to fashion a jurisdictional scheme for the ICC that would be sufficiently aggressive to make the court effective in the prosecution of criminals but also sufficiently consensual to make the court a suitable institution for the adjudication of international disputes. A genuine quandary is posed by the need for a jurisdictional structure that will foster the ICC's effectiveness as a criminal court without engendering overreaching by the ICC into areas of interstate dispute settlement in which states have legitimate rights of discretion regarding methods and fora. The following discussion attempts to gain some purchase on the issue of the ICC's ju- 
risdiction over non-party nationals by considering the court's jurisdictional structure in the light of this dilemma.

This article begins by examining the interests of states with respect to the jurisdiction of international courts and the consequent patterns in the jurisdictional structures of existing international courts. That section will conclude by evaluating the significant differences between the jurisdictional structure of the ICC and that of other international courts in light of the ICC's dual character as the adjudicator of individual culpability and of interstate legal disputes. Proceeding from that analytic basis, the subsequent sections will examine the strengths and the shortcomings of the theories supporting ICC jurisdiction over non-party nationals. The article will conclude that the ICC's jurisdictional structure and, more specifically, its provision for jurisdiction over non-party nationals, cannot be satisfactorily justified and that this is so, ultimately, because the ICC's role as an adjudicator of interstate disputes is not adequately accounted for in the Court's jurisdictional design.

\section{II}

\section{THE JURISDICTION TO ADJUDICATE INTERSTATE DISPUTES}

States are notoriously reluctant to submit their disputes to binding thirdparty adjudication. Despite a dramatic increase in the use of binding thirdparty adjudication at the international level in recent years, the use of such mechanisms to resolve international disputes remains minimal in comparison with the use of diplomatic means for addressing such disputes. The relative dearth of interstate disputes brought to the ICJ has given rise to extended consideration of why states make such limited use of the ICJ and how greater use might be encouraged. ${ }^{5}$ The fact, quickly noted in discussions of the limited state use of the ICJ, is that states-perhaps more specifically, foreign ministry officials-are reluctant to relinquish control over their disputes to third parties, on either an ad hoc or a compulsory basis. ${ }^{6}$ Such reluctance may be partly explained by states' concerns with a court's procedures or structure. ${ }^{7}$ But even in

5. See, e.g., John G. Merrills, InTERnAtional Dispute SETTLEMENT 164-66, 285-311 (3d ed. 1998); K. Hubbard, Separation of Powers Within the United Nations: A Revised Role for the International Court of Justice, 38 STAN. L. REV. 165, 168 (1985); Arthur Rovine, The National Interest and the World Court, in I THE Future of THE INTERNATIONAL COURT OF JUSTICE (Leo Gross ed., 1976); Gerald Fitzmaurice, Enlargement of the Contentious Jurisdiction of the Court, in II THE FUTURE OF THE INTERNATIONAL COURT OF JUSTICE 461-98 (Leo Gross ed., 1976); JUDICIAL SETTLEMENT OF INTERNATIONAL Disputes (H. Mosler \& R. Bernhardt eds., 1974); L.V. Prott, The Future of the International Court of Justice, 33 Y.B. WORLD AFF. 284 (1979).

6. See Rovine, supra note 5, at 317; Richard Bilder, Some Limitations of Adjudication as an International Dispute Settlement Technique, 23 VA. J. INT'L L. 1, $2-4$ (1982); Richard Falk, Realistic Horizons for International Adjudication, 11 VA. J. INT'L L. 315, 321-22 (1971).

7. See Leo Gross, The International Court of Justice: Consideration of Requirements for Enhancing Its Role in the International Legal Order, in I THE FUTURE OF THE INTERNATIONAL COURT OF JUSTICE 22-104 (Leo Gross ed., 1976); Edvard Hambro, Will the Revised Rules of Court Lead to Greater Willingness on the Part of Prospective Clients?, in I THE FUTURE OF THE INTERNATIONAL COURT OF JUSTICE 365-76 (Leo Gross ed., 1976); Leo Gross, Review of the Role of the International Court of Justice, 66 AM. J. INT’L L. 479 (1972). 
the absence of such concerns, there is a more fundamental reluctance to submit to third-party adjudication that rests on the perceived advantages to states in some circumstances of retaining control over the resolution of their disputes. ${ }^{8}$ As Arthur Rovine has put it, "[i]t is one thing to show that resort to the ICJ is preferable to war or armed conflict; it is quite another matter to demonstrate that judicial processes are as valuable as ordinary out-of-court bargaining and discussion." $"$

When a dispute involving allegations of war crimes, genocide, or crimes against humanity involves unsettled law or ambiguous facts, compulsory binding adjudication may not be the most constructive or appropriate method of dispute resolution. While the most flagrant instances of, say, genocide leave no basis for dispute or negotiation, many cases involving allegations of genocide, crimes against humanity, or, especially, war crimes are more complex, factually or legally or both.

Resolving interstate disputes through negotiation and other diplomatic means often is perceived by states as less risky and potentially more constructive than submitting the disputes for third-party adjudication. This is so for a number of reasons. Diplomatic approaches maintain the possibility of leaving the issue in abeyance should matters develop such that non-resolution appears preferable to immediate resolution..$^{10}$ Diplomatic methods are likely to result in less damage to the standing and prestige of the losing state, if there is in fact an identifiable loser. This consideration is heightened in cases where a loss would entail a finding that the losing state had been engaged in wrongdoing. In addition, diplomatically negotiated resolutions do not create legal precedents in the way that reasoned and published legal opinions inevitably do. States may fear the creation of an authoritative (even if not binding) precedent contrary to their interests and, moreover, may object to the prospect of an international court, in effect, legislating international law where the litigated issue concerns an unsettled area of law. ${ }^{11}$ Another influential factor is that, in a dispute between any two states, one party is likely to have a political advantage, a stronger bargaining position, that would be significant in the diplomatic arena but might be of little effect in an adjudicated settlement. ${ }^{12}$ Moreover, diplomacy leaves room for compromise resolutions that adjudication generally does not. ${ }^{13}$ Retaining control over a dispute allows states to respond in a nimble and nuanced way as a controversy and the options for its resolution unfold. All of this states are unwilling to give up wholesale.

8. See Rovine, supra note 5; Fitzmaurice, supra note 5, at 462-73.

9. Rovine, supra note 5, at 314.

10. See id. at $317,319$.

11. See Paul Szasz, Enhancing the Advisory Competence of the World Court, in II THE FUTURE OF THE INTERNATIONAL COURT OF JUSTICE 499-549 (Leo Gross ed., 1976) ("[T]he prospect that increased activity by the Court will help fill interstices in the international legal fabric or even expand its bounds, is likely to constitute, among diplomats, a negative rather than a positive argument for [enhancing the court's caseload]."); Rovine, supra note 5, at 315-16.

12. See id. at 319-20.

13. See Bilder, supra note 6, at 2-4; Falk, supra note 6, at 321-22; Rovine, supra note 5, at 317. 
Generally, the more important and sensitive the subject of a dispute is to a state, the less willing the state is to submit the dispute for third-party adjudication. $^{14}$ Equally, the more uncertain the adjudicated outcome of a particular dispute would be, the less willing a state will be to submit to binding third-party adjudication. ${ }^{15}$ By extension, if states frequently are unwilling to submit for adjudication disputes that are important and whose adjudicated outcomes would be uncertain, states also will be unwilling to make broad grants of jurisdiction in advance that could later prove to include important disputes whose adjudicated outcomes would be uncertain. As Professor John Merrills has observed,

$[\mathrm{P}]$ robably the most striking feature of adjudication is that it is dispositive. Because the decisions of courts and tribunals are treated as binding, litigation is a good way of disposing of a troublesome issue when the resolution of a dispute is considered to be more important than the result. Conversely, when the result is all-important, adjudication is unlikely to be used because it is simply too risky. These attitudes are reinforced by the fact that adjudication is not merely dispositive, but tends to produce a winner-takes-all type of solution. This can obviously render an unfavourable outcome a catastrophe and so encourages states to choose other procedures for disputes which they cannot afford to lose.

Because adjudication is dispositive the attitude of states toward compulsory jurisdiction is conspicuously ambivalent. On the one hand, there is a good deal of support for the principle of the optional clause and similar arrangements [allowing states to consent in advance to the jurisdiction of an international court over future disputes, subject to such reservations as each state may make], since the idea of establishing a binding system to resolve international disputes is an attractive one. On the other hand, as soon as such arrangements are established, states become aware of the risks involved in a commitment to litigate disputes which cannot be foreseen and begin to have second thoughts. The result ... is a reluctance to subscribe to the more general arrangements for compulsory jurisdiction and a preference for agreements concerned either with particular types of cases or individual disputes. ${ }^{16}$

Certainly, states sometimes do choose to submit their disputes for thirdparty adjudication. But, cognizant of both the advantages and the drawbacks of adjudication, states jealously guard their prerogative to select the circumstances under which they will do so. States' insistence on this prerogative has, in general, been viewed as legitimate (even while many have sought to expand consensual use of the $\mathrm{ICJ}^{17}$ ) and has been reflected in the treaties providing for third-party adjudicatory mechanisms.

All existing international courts have contentious jurisdiction ${ }^{18}$ only over disputes involving states that are parties to treaties providing for their jurisdiction. $^{19}$ Inspection of those treaties reveals that, in general, states have not seen 20.

14. See Falk, supra note 6, at 321; Fitzmaurice, supra note 5, at 488;. Rovine, supra note 5, at 319-

15. See Fitzmaurice, supra note 5, at 473; Szasz, supra note 11, at 511.

16. MERRILLS, supra note 5, at 293-94.

17. See, e.g., sources cited supra note 5 .

18. The contentious jurisdiction of an international court is the court's jurisdiction to decide interstate disputes as distinct from its authority to render advisory opinions or to exercise other, incidental powers.

19. See United Nations, Handbook on the Peaceful Settlement of Disputes Between STATES 70 (1992) ("Settlement of international disputes by international courts is subject to the recognition by the states concerned of the jurisdiction of the courts over such disputes."). 
fit to relinquish discretion over jurisdiction entirely, even by treaty. Rather, the treaties establishing international courts have been designed to afford states parties significant continuing discretion over the powers that the respective courts will have relative to jurisdiction and, relatedly, to remedies. This is true of the ICJ, the Tribunal on the Law of the Sea, and the WTO dispute settlement system, which will serve as three principal examples, as well as of other international courts. ${ }^{20}$

The contentious jurisdiction of the ICJ depends on the consent of the states that are parties to the dispute. ${ }^{21}$ Consent to ICJ jurisdiction may be given in advance either through a compromissory clause in a treaty providing that some or all categories of disputes arising under that treaty will be submitted to the ICJ or through a declaration under the ICJ Statute's "optional clause." 22 By making

20. See generally id.; MERRILLS, supra note 5 (providing a survey of the jurisdictional and other features of international dispute resolution mechanisms); INTERNATIONAL DISPUTES: THE LEGAL AsPECTS (C.M.H. Waldock ed., 1972) (same).

The European Court of Justice ("ECJ") and the European Court of Human Rights ("ECHR") provide contrasting examples insofar as each has automatic jurisdiction over states parties to the treaties establishing the court. On examination, however, we see that neither of those courts in fact constitutes a counterexample to the proposition that states generally maintain significant continuing discretion over the powers that international courts will have relative to jurisdiction and, relatedly, to remedies.

The ECJ must be distinguished from other international courts because it is the court of the European Communities. The European Communities, even while they are constituted by inter-state organizations, are part of a system of close regional economic integration. We would expect that the degree of authority that member states would be willing to vest in the European Communities' court would be greater than that which states would ordinarily be willing to vest in an international court that was not a constitutive part of an integrated regional economic system.

The ECHR, by contrast, is a creature of the Council of Europe. See Francis JACOBS \& RobIN White, THE European CONVENTION ON Human Rights 3-4 (1996). The ECHR has jurisdiction over all matters concerning the interpretation and application of the European Convention on Human Rights, including violations by states parties of that convention and the human rights delineated therein. European Convention on Human Rights arts. 32(1), 33, 34. However, while the jurisdiction of the ECHR is compulsory, the provisions for remedies and for enforcement of ECHR decisions leave those matters to be decided largely through diplomatic and political processes within the Council of Europe. Where the court finds that a state party has committed a violation, its judgment will so indicate and provide the reasons for its finding. It may also award compensation and costs. See LUKE Clements et AL., European Human Rights: TAKING A CASE Under THE CONVENTION 103 (1999). It will not, however, specify other measures, such as legal or structural reforms, that the offending state party might need to take to remedy the violation (for example, where the violation is ongoing). See id. The convention provides that "[t]he judgment of the Court shall be transmitted to the Committee of Ministers which shall supervise its execution." European Convention on Human Rights art. 46(2). The Committee of Ministers is comprised of the foreign ministers of the member states of the Council of Europe. See ClEMENTS ET AL., supra, at 9-10. That Committee, in some cases, then negotiates with the offending state party concerning what remedial measures will be taken. The convention does not provide for sanctions for failure to implement an ECHR decision. Therefore, the actions that may be taken by the Committee of Ministers in negotiating the remedial measures for an ECHR decision and in ensuring its enforcement are limited to various forms of political pressure. See JACOBS \& WHITE, supra, at 398. In sum, the power ceded to the ECHR in the court's jurisdictional structure is somewhat qualified by the remedial and enforcement structures. ICJ).

21. See generally MERRILLS, supra note 5, at 121-45 (on the organization and procedures of the

22. See Statute of the International Court of Justice, June 26, 1945, art. 36(2), 59 Stat. 1055, 3 Bevans 1179 [hereinafter ICJ Statute]. 
a declaration under the optional clause, a state agrees to accept the ICJ's jurisdiction for some or all categories of future disputes.

A compromissory treaty clause giving jurisdiction to the ICJ tends to be more readily acceptable to states where the clause concerns a narrowly defined subject matter $^{23}$ than where the jurisdiction conferred is more open-ended. ${ }^{24}$ State practice in the use of the optional clause of the ICJ Statute shows similar tendencies for states to be conservative with regard to making grants of jurisdiction in advance. Fewer than a third of the members of the United Nations currently have in force declarations under the optional clause, ${ }^{25}$ and many of those states have made reservations substantially limiting the effect of their declarations. $^{26}$

If consent to ICJ jurisdiction covering a given dispute has not been expressed in advance, the dispute may nevertheless be submitted for ICJ adjudication by special agreement of the parties. ${ }^{27}$ In making such a special agreement, the parties may frame the legal issue in dispute and, to some extent, the basis on which the court should decide the issue. ${ }^{28}$ Even in cases when the ICJ would have jurisdiction on another basis, the parties may choose for the ICJ to adjudicate pursuant to a special agreement. ${ }^{29}$

The jurisdiction of the ICJ, based as it is on a combination of compromissory clauses, optional-clause declarations, and special agreements, is quite thoroughly consent-based. Unsurprisingly, controversies have arisen regarding whether the interests of a non-consenting, third-party state would, in effect, be adjudicated in a case brought by other parties before the court. In the Montary Gold case, four states that wished to submit a dispute for adjudication had all accepted ICJ jurisdiction. The ICJ nevertheless declined to adjudicate the case because Albania, whose property rights were the subject of the dispute, had not

23. See, e.g., Optional Protocol to the Vienna Convention on Diplomatic Relations Concerning the Compulsory Settlement of Disputes, Apr. 18, 1961, T.I.A.S. 7502, 500 U.N.T.S. 241, attached to the Vienna Convention on Diplomatic Relations, Apr. 18, 1961, T.I.A.S. 7502, 500 U.N.T.S. 95; Optional Protocol to the Vienna Convention on Consular Relations Concerning the Compulsory Settlement of Disputes, Apr. 24, 1963, T.I.A.S. 6820, 596 U.N.T.S. 487, attached to the Vienna Convention on Consular Relations, Apr. 24, 1963, T.I.A.S. 6820, 596 U.N.T.S. 261. The Optional Protocol and Convention of 1961 have 61 and 174 parties respectively. The Optional Protocol and Convention of 1963 have 44 and 153 parties respectively. See Christian L. WiKtOR, Multilateral Treaty CALENDAR 1648-1994, at 726-27 (1998).

24. See, e.g., American Treaty on Pacific Settlement, Apr. 30, 1948, 30 U.N.T.S. 55 ("Pact of Bogata"); European Convention for the Peaceful Settlement of Disputes, Apr. 29, 1957, 320 U.N.T.S. 243, each of which has 13 states parties, many of whom have attached significant reservations. See WIKTOR, supra note 23 , at $485,657$.

25. See MERRILls, supra note 5, at 123; see also John Merrills, The Optional Clause Revisited, 64 BRIT. Y.B. INT'L L. 197 (1993) (analyzing states' practice in use of the optional clause).

26. See id. See generally, Szasz, supra note 11, at 511 (observing that "[s]tates are reluctant to submit to international courts, particularly in broad terms and in advance").

27. See ICJ Statute, supra note 22, art. 36(1); UNITED NATIONS, supra note 19, at 71-72, and sources cited therein.

28. See MERRILls, supra note 5, at 122-23.

29. See, e.g., Arbitral Award Made by the King of Spain on Dec. 23, 1906 (Hond. v. Nicar.), 1960 I.C.J. 192 (judgment of Nov. 18) (exercising jurisdiction pursuant to a special agreement notwithstanding that the court also would have had jurisdiction on other bases). 
so consented. ${ }^{30}$ The principle of the Monetary Gold decision has subsequently been further clarified. In the Nicaragua case, the ICJ held that the requirement for consent to jurisdiction by each party to the dispute applied only where the legal interests of the non-consenting state "would not only be affected by a decision, but would form the very subject matter of the decision."

The ICC Treaty's jurisdictional provisions stand in stark contrast to those of the ICJ Statute. In ICC cases in which a state's national is prosecuted for an official act that the state maintains was lawful or that the state maintains did not occur, the lawfulness or the occurrence of that official state act-that is, the question whether the state had a right to take such action or whether it did so-would "form the very subject matter of the dispute." Yet, by the terms of the ICC Treaty, the ICC would exercise jurisdiction in that case with or without the consent of the state whose official acts would form the subject of the adjudication.

Not only the ICJ with its open-ended subject-matter jurisdiction, but also international courts of limited subject-matter jurisdiction have jurisdictional structures reserving significant discretion to states. Two principal examples of such courts are the Tribunal on the Law of the $\mathrm{Sea}^{32}$ and the WTO dispute settlement mechanism. ${ }^{33}$

The United Nations Convention on the Law of the Sea ("UNCLOS") provides that, if states are unable to settle their disputes relating to the convention through a prompt "exchange of views," Procedures Entailing Binding Decisions" come into operation. ${ }^{35}$ Those procedures afford states an array of methods of binding dispute resolution from which they may select.

UNCLOS provides that each state party shall make a declaration accepting the jurisdiction of at least one of four enumerated tribunals: the International Tribunal for the Law of the Sea, the ICJ, an arbitral tribunal, and a special arbitral tribunal. If both parties have accepted the same tribunal, then that tribunal

30. See Monetary Gold Removed from Rome in 1943 (Italy v. Fr., U.K., N. Ir., and U.S.), 1954 I.C.J. 19 (June 15).

31. Concerning Military and Paramilitary Activities in and Against Nicaragua (Nicar. v. U.S.), 1984 I.C.J. 431 (Jurisdiction and Admissibility Judgment of Nov. 26); see also Certain Phosphate Lands in Nauru (Nauru v. Austl.), 1992 I.C.J. 240 (Preliminary Objections and Judgment of June 26) (following same rationale); Concerning East Timor (Port. v. Austl.), 1995 I.C.J. 90 (Judgment of June 30) (same).

32. United Nations Convention on the Law of the Sea, Dec. 10, 1982, annex VI, Statute for the International Tribunal for the Law of the Sea, 21 I.L.M. 1345.

33. Agreement Establishing the World Trade Organization, Apr. 15, 1994, annex 2, Understanding on Rules and Procedures Governing the Settlement of Disputes, 33 I.L.M. 1226 [hereinafter DSU].

For comprehensive treatments of the mechanisms for settlement of interstate disputes on specified subject areas, see UNITED NATIONS supra note 19, 135-53; INTERNATIONAL DISPUTES: THE LEGAL ASPECTS, supra note 20, ch. 4.

34. United Nations Convention on the Law of the Sea, opened for signature Dec. 10, 1982, art. 283, 21 I.L.M. 1261 [hereinafter UNCLOS].

35. See id. part IV $\S 2$. The convention also provides for a specialized Sea-Beds Dispute Chamber with jurisdiction specific to disputes regarding the convention's arrangements regarding the deep seabed. See MERRILLS, supra note 5, at 187- 90. 
(or another to which both parties agree) will be used. In the absence of such a match, the dispute may be referred to arbitration.

In addition to the considerable flexibility afforded by UNCLOS regarding methods of binding settlement, the convention also exempts from the compulsory settlement system certain subject areas. ${ }^{36}$ Article 297 exempts from compulsory settlement those disputes that relate to enumerated areas involving the sovereign rights of coastal states. ${ }^{37}$ Article 298 permits exemption, at the option of each state party, of disputes relating to sea boundary delimitations and related matters, disputes being addressed by the U.N. Security Council and, most significantly for comparison with the ICC, disputes concerning military activities. $^{38}$ For disputes concerning these specified subject areas, the UNCLOS dispute settlement mechanisms that are otherwise applicable are available, but can be used only with the consent of all parties to the dispute..$^{39}$ The UNCLOS dispute resolution mechanisms thus retain considerable discretion for states regarding the forms of binding third-party settlement that they will accept and, equally significantly, allow states to exempt entirely from compulsory jurisdiction disputes concerning particularly sensitive areas, including military activities.

The dispute settlement system for the World Trade Organization is organized in rather a different way, still reserving to states significant flexibility relating to third-party adjudications, but providing that flexibility more in the remedy provisions than in the jurisdictional structure. The WTO Dispute Settlement Understanding ${ }^{40}$ provides that, when diplomatic means are unavailing in resolving a dispute arising under the covered trade agreements, ${ }^{41}$ the dispute will be settled through the Dispute Settlement Body ("DSB"). In somewhat simplified form, the Dispute Settlement Understanding provides that the DSB will create a panel that will assess the facts and law of the dispute and "make such other findings as will assist the DSB in making the recommendation or in giving the rulings provided for in the covered agreements." ${ }^{42}$ The panel's final report must, within sixty days of its submission, be adopted by the DSB unless either there is a consensus within the DSB not to adopt or a party has given notice of appeal. ${ }^{43}$ Appeals are limited to issues of law. ${ }^{44}$ The appellate report is submitted to the DSB and must be unconditionally accepted by the parties unless the DSB decides by consensus not to adopt the report. ${ }^{45}$

\footnotetext{
36. See UNCLOS, supra note 34, arts. 297-98.

37. See id. art. 297.

38. See id. art. 298.

39. See id. art. 299.

40. See DSU, supra note 33 .

41. See id. arts. 4-5.

42. See id. art. 11.

43. See MERRILLS, supra note 5, at 205-08.

44. See DSU, supra note 33, art. 17(6).

45. See id. art. 17(14).
} 
The WTO dispute settlement system thus provides little flexibility as to procedures and mechanisms. Perhaps as a consequence, substantial discretion is left to states elsewhere in the dispute settlement system. The remedy mechanism introduces considerable flexibility.

The possible remedies for violations of the covered trade agreements are several, ranging from the offending state's promptly bringing its practice into compliance, to that state's indicating that the practice will remain out of compliance "temporarily" (for an unspecified period) and then either paying compensation or doing nothing at all and standing subject to retorsion by the opposing state. ${ }^{46}$ More specifically, when a panel report or, in case of appeal, the Appellate Body report holds that a state's trade measure is inconsistent with a covered agreement, the report must recommend that the measure be brought into compliance. ${ }^{47}$ Within thirty days of adoption of that report, the state concerned must indicate its intentions relative to implementing that recommendation. $^{48}$ In the event that the compliance recommendation is not implemented within a reasonable period, ${ }^{49}$ the offending state is obliged to negotiate with the complaining state "with a view to developing mutually acceptable compensation." ${ }^{, 50}$ If no compensation arrangement has been agreed to within a reasonable period, then the complaining state may request the DSB to authorize countermeasures. $^{51}$ More precisely, the complaining state may request that the DSB authorize suspension of the complaining state's concessions or other obligations under the covered agreement in relation to the state in default. ${ }^{52}$ By such a suspension of concessions and obligations, the complaining state is freed to take countermeasures. Should the level of countermeasures permitted be disputed by the offending state, then that level may be set by binding arbitration. ${ }^{53}$

The net result of such a suspension of concessions and obligations is, in a sense, to return the disputing parties to a regime of diplomatic, nonadjudicatory dispute resolution relative to the specific issue in dispute. Certainly, that diplomatic process would proceed very much in the light of the fact that the DSB had identified a violation and had authorized countermeasures. But the dispute would have been returned, in that posture, for diplomatic resolution by the parties. In that way, even while the WTO dispute settlement system provides for compulsory third-party decisionmaking, the remedial mechanism is designed in such a way that, if an offending state chooses neither to bring its practice into compliance nor to pay compensation, it may return the dispute to the realm of diplomatic interstate dispute resolution. Thus, states partially recover in the remedy provisions the discretion regarding methods of

46. See id. arts. 19-22.

47. See id. art. 19(1).

48. See id. art. 21.

49. Regarding determination of reasonable time periods, see $i d$.

50. See id. art. 22(2).

51. See id. art. 22.

52. See id.

53. See id. art. 22(6). 
dispute resolution that they give up in the jurisdictional aspects of the WTO dispute settlement system.

We should note also, before leaving our discussion of the WTO dispute settlement system, the national security exception in the WTO system. Article XXI of the General Agreement on Tariffs and Trade, which forms a major part of the substantive law of the WTO, provides that

[n]othing in this Agreement shall be construed

(a) to require any contracting party to furnish any information the disclosure of which it considers contrary to its essential security interests; or

(b) to prevent any contracting party from taking any action which it considers necessary for the protection of its essential security interests

(i) relating to fissionable materials or the materials from which they are derived;

(ii) relating to traffic in arms, ammunition and implements of war and to such traffic in other goods and materials as is carried on directly or indirectly for the purpose of supplying a military establishment;

(iii) taken in time of war or other emergency in international relations; or

(c) to prevent any contracting party from taking any action in pursuance of its obligations under the United Nations Charter for the maintenance of international peace and security. ${ }^{54}$

Here we see, once again, that even when states are willing to grant some degree of authority over settlement of interstate disputes to a third-party decisionmaker, military and security-related matters are frequently exempted from that jurisdiction.

In looking at the relevant provisions of the ICJ Statute, UNCLOS, and the WTO's Dispute Settlement Understanding, we have seen that each treaty provides to states considerable discretion over the degree and type of authority that the respective courts will have over interstate disputes. The jurisdictional provisions of the ICC Treaty, by contrast, provide for no such discretion. Rather, the ICC Treaty provides that the ICC may exercise jurisdiction over the national of any state when crimes within the court's subject-matter jurisdiction are alleged to have been committed on the territory of a state that has consented to the court's jurisdiction. ${ }^{55}$

54. General Agreement on Tariffs and Trade, Oct. 30, 1947, art. XXI, 61 Stat. A3, 55 U.N.T.S. 187.

55. The ICC Treaty contains "admissibility" provisions that would deprive the ICC of the authority to exercise its jurisdiction under certain circumstances. A case is not admissible before the ICC if

(a) [t]he case is being investigated or prosecuted by a state which has jurisdiction over it, un-

less the state is unwilling or unable genuinely to carry out the investigation or prosecution;

(b) [t]he case has been investigated by a state which has jurisdiction over it and the state has

decided not to prosecute the person concerned, unless the decision resulted from the unwillingness or inability of the state genuinely to prosecute.

ICC Treaty, supra note 1, art. 17(a), (b). But those admissibility provisions do not address the fact that the state whose official acts are at issue may view those acts as lawful and, therefore, may see no basis for investigation or prosecution. In addition, the treaty leaves undefined the type and extent of investigation required, the circumstances in which prosecution is required after investigation, and how much information about the investigation (including potentially sensitive data) may be required to satisfy the Court that the state has met its burden in demonstrating that it is neither unwilling nor unable to han- 
On the surface, the very easy explanation for this difference in the nature of the ICC's jurisdiction from that of other international courts is that the other courts' purpose is to adjudicate disputes between states while the ICC's purpose is to adjudicate the criminal liability of individuals. If individuals have committed the crimes of genocide, war crimes, or crimes against humanity, which the community of states has already agreed are serious international crimes, then their prosecution can hardly be likened to a dispute between states. This difference between the missions of the ICC and other international courts might be thought entirely to justify the uniquely non-consensual basis of ICC jurisdiction.

To some extent, this explanation is cogent. For ICC cases concerned strictly with individual culpability, the ICC will have much in common with municipal criminal courts and relatively little in common with the other international courts such as the ICJ. As noted earlier, however, a complexity arises from the fact that, in addition to cases that are purely of the individual-culpability type, the ICC also will hear cases in which official acts-acts that the state in question maintains were lawful or whose very occurrence the state disputes-form the basis for an indictment. ${ }^{56}$ In such cases, the lawfulness of the official acts of states will be adjudicated by the ICC. When the ICC is operating in this capacity, it will have less in common with municipal criminal courts and a great deal in common with other international courts such as the ICJ.

Since cases before the ICC will necessarily involve allegations of genocide, war crimes, or crimes against humanity, ${ }^{57}$ the subject matter of an ICC case of the interstate-dispute type will likely be considered important and sensitive by the involved states. The probable involvement of military activities would tend to heighten the sensitive nature of the cases. And, given the relatively undeveloped state of the law in this field ${ }^{58}$ the adjudicated outcome of such a dispute is likely to be uncertain. Such disputes, then, are of precisely the sort that states are most reluctant to submit for third-party adjudication. ${ }^{59}$ While the prerogative of states to choose whether to adjudicate such disputes is protected in the ICJ Statute and other international court treaties, that prerogative has been overlooked in the drafting of the ICC Treaty.

This oversight may be attributable in part to the drafters of the ICC Treaty's having viewed the ICC primarily in its capacity as a criminal court determining individual guilt or innocence. Perhaps, in addition, some states wished to use ICC jurisdiction to effectuate a change in interstate power relations by moving an important category of interstate disputes out of the diplomatic realm and

dle the matter properly at the national level. Therefore, while the admissibility provisions do ameliorate the problems of ICC jurisdiction, those provisions do not adequately respond to the concerns arising from the ultimate fact that the ICC's jurisdiction does not require that the defendant's state of nationality be a party to the treaty or otherwise consent to ICC jurisdiction.

56. The two different types of cases that will come before the ICC may not appear as pure types; any given case may have elements of each. For purposes of analysis, however, it will be useful to distinguish between cases of these two distinct characters.

57. See supra note 2 and accompanying text.

58. See infra text accompanying notes 74-81.

59. See supra text accompanying notes 5-17. 
into that of compulsory adjudication. As Arthur Rovine has noted, "weaker states derive an obvious advantage from legal settlement in disputes with more powerful opponents... . Clearly, the strong give up much of their leverage in a contest of legal briefs and argumentation." ${ }^{60}$ Or some participants in the ICC negotiations may have wished to expand the power of international institutions, including courts, without regard to the resultant redistribution of power among particular states.

Whatever the motivating factors were, the failure to protect states' prerogatives regarding jurisdiction over interstate disputes was bound to engender significant resistance to the ICC Treaty, some of which has already been manifested. ${ }^{61}$ In addition to these political consequences, the failure to retain states' discretion regarding jurisdiction over interstate disputes also has legal implications that must be taken into account in any comprehensive analysis of the lawfulness of ICC jurisdiction over non-party nationals.

A number of theories have been advanced in support of the lawfulness of ICC jurisdiction over non-party nationals. While some of these theories have considerable initial appeal, none ultimately provides a satisfactory foundation for the form of jurisdiction claimed for the ICC. The shortcomings of these theories, as we shall see, are largely attributable to the fact that the jurisdictional provisions and the theories offered in their support focus on ICC cases of the individual-culpability type without attending to the legal implications of the fact that the ICC will also adjudicate cases of the interstate-dispute variety.

III

\section{THEORIES OF DELEGATED JURISDICTION}

As reflected in the Vienna Convention on the Law of Treaties, ${ }^{62}$ treaties cannot "create ... obligations" for non-parties. ${ }^{63}$ The United States has claimed that the ICC Treaty, by providing for ICC jurisdiction over non-party nationals, violates this principle of the law of treaties. ${ }^{64}$ The United States may have stated its complaint somewhat too simply. The ICC Treaty does not, per se, impose "obligations" (in the sense of duties or responsibilities) on non-parties by providing for jurisdiction over their nationals. ${ }^{65}$

The legal objection to ICC jurisdiction over non-party nationals is perhaps better articulated as a claim that, by conferring upon the ICC jurisdiction over non-party nationals, the ICC Treaty would abrogate the pre-existing rights of non-parties which, in turn, would violate the law of treaties. As the International Law Commission's official Commentaries on the Vienna Convention

60. Rovine, supra note 5, at 319.

61. See supra text accompanying notes 4 \& 204.

62. Opened for signature May 23, 1969, arts. 34-38, 1155 U.N.T.S. 331, 8 I.L.M. 679.

63. See id. art. 34.

64. See supra text accompanying note 4.

65. See Philippe Kirsch, The Rome Conference on the International Criminal Court: A Comment, ASIL NEWSLETTER 1 (Nov./Dec. 1998). 
state, "[i]nternational tribunals have been firm in laying down that in principle treaties, whether bilateral or multilateral, neither impose obligations on States which are not parties nor modify in any way their legal rights without their consent." ${ }^{66}$ As Judge Huber stated succinctly in the Island of Palmas arbitration, "whatever may be the right construction of a treaty, it cannot be interpreted as disposing of the rights of independent third Powers." ${ }^{67}$ ICC jurisdiction over non-party nationals would appear to be exorbitant jurisdiction under international law, as shall be discussed below. The right of a state to be free from the exercise of exorbitant jurisdiction over its nationals cannot be abrogated by a treaty to which it is not a party.

The legal basis for objection to ICC jurisdiction over non-party nationals turns, then, on the proposition that such jurisdiction would be exorbitant under the international law of jurisdiction. This proposition therefore requires careful scrutiny. The first critical question will be whether the traditional bases for states' jurisdiction provide a legal foundation for ICC jurisdiction over nonparty nationals. If, for example, the jurisdiction to be exercised by the ICC were the pre-existing jurisdiction of states parties which they had delegated to the court, then, arguably, the ICC Treaty, far from conferring exorbitant jurisdiction, would be merely an agreement among the states parties regarding the manner in which they would exercise their lawful jurisdiction. Two plausible theories of ICC jurisdiction as delegated state jurisdiction will be examined here: delegated universal jurisdiction and delegated territorial jurisdiction. After concluding that neither of those theories, nor, indeed, any of the traditional bases for states' jurisdiction, provides a legal foundation for ICC jurisdiction over non-party nationals, we will then consider whether such jurisdiction would nevertheless be lawful as a new form of jurisdiction.

\section{A. Delegated Universal Jurisdiction}

The ICC Treaty provides that the ICC may exercise jurisdiction over nonparty nationals, without consent by the state of nationality or referral by the Security Council, only if the alleged crime was committed on the territory of a state party. Notwithstanding this territoriality requirement, some proponents of the ICC Treaty have contended that ICC jurisdiction over the nationals of nonparty states is based, fundamentally, upon the principles of universal jurisdiction pursuant to which the courts of any state may prosecute the nationals of any state for certain serious international crimes. Since any individual state could prosecute perpetrators regardless of their nationality, they reason, a

66. Report of the International Law Commission on the Work of its Eighteenth Session, Draft Articles on the Law of Treaties with Commentaries, II YEARBOOK OF THE INT'L L. COMM'N 226 (1966) (Commentary to Draft Art. 30, "General Rule Regarding Third states") (emphasis added); see also ARNOLD MCNAIR, THE LAW OF TREATIES 321 (1961) ("A State which learns that a treaty concluded between two other States has for its object or probable consequence the impairment of its rights, whether enjoyed under customary international law or under a treaty with one of the contracting parties, is entitled at once to lodge a diplomatic protest with those parties and to apply to the International Court of Justice . . f for a declaration and . . for interim measures of protection.").

67. Island of Palmas: 2 U.N.R.I.A.A. 829, 842. 
group of states may create an international court empowered to do the same. Under this theory, each state party, in effect, delegates to the international court its power to exercise universal jurisdiction. Advocates of this view reason that the territoriality requirement simply reflects a choice that the ICC will exercise only part of the full range of jurisdiction that it legally could exercise under the customary law of universal jurisdiction. ${ }^{68}$

For ease of exposition, the theory of ICC jurisdiction over non-party nationals as delegated universal jurisdiction will be considered first, and the theory based on delegated territorial jurisdiction will be considered below.

The theory of delegated universal jurisdiction as a basis for ICC jurisdiction confronts two difficulties. The first is that the theory fails to account for the ICC's jurisdiction over a number of crimes that the Treaty places within the subject-matter jurisdiction of the ICC but which are not subject to universal jurisdiction. Certain violations of Protocol I to the Geneva Conventions of $1949,{ }^{69}$ for instance, are not subject to universal jurisdiction under customary law. ${ }^{70}$ For example, conscription of child soldiers, prohibited under Protocol I and elsewhere, is placed within the jurisdiction of the court by the terms of the ICC Treaty, $^{71}$ but is not a crime customarily subject to universal jurisdiction. ${ }^{72}$ A delegated universal jurisdiction theory of ICC jurisdiction over non-party nationals thus would not account for jurisdiction over some of the crimes within the jurisdiction of the court under the Treaty.

Perhaps the inclusion of crimes not customarily subject to universal jurisdiction should be viewed as a "proposal", in effect, that customary law henceforth

68. As Professor Scharf puts it,

the drafters did not view the consent of the state of territoriality or nationality as necessary as a matter of international law to confer jurisdiction on the court. Rather, they adopted the consent regime as a limit to the exercise of the court's inherent jurisdiction as a politically expedient concession to the sovereignty of states in order to garner broad support for the statute.

Michael Scharf, The ICC's Jurisdiction Over the Nationals of Non-Party states: A Critique of the U.S. Position, 64 LAW \& CONTEMP. PROBS. 67, 77 (Winter 2001).

69. Protocol Additional to the Geneva Conventions of 12 August 1949, and Relating to the Protection of Victims of International Armed Conflicts (Protocol I), June 8, 1977, 1125 U.N.T.S. 3.

70. See Ruth Wedgwood, The International Criminal Court: An American View, 10 EUR. J. INT'L L. 93, 102 (1999).

71. See ICC Treaty, supra note 1 , art. 8 (xxvi).

72. The prohibition on recruitment of children under 15 years of age for service in armed forces, and the obligation to take measures to ensure that such children do not participate in hostilities, appear in the two 1977 Protocols to the Geneva Conventions as well as in the U.N. Convention on the Rights of the Child. See Protocol Additional to the Geneva Conventions of 12 August 1949, and Relating to the Protection of Victims of International Armed Conflicts (Protocol I), supra note 69, art. 77(2); Protocol Additional to the Geneva Conventions of August 12, 1949, and Relating to the Protection of Victims of Non-International Armed Conflicts (Protocol II), June 8, 1977, art. 4(3)(c) 1125 U.N.T.S. 609; Convention on the Rights of the Child, Nov. 20, 1989, art. 38, 28 I.L.M. 1457. In none of those treaties is there any suggestion that violations of the child soldier provisions constitute grave breaches or otherwise give rise to universal jurisdiction. Nor is there any other basis for a claim that utilization of child soldiers constitutes an international crime entailing universal jurisdiction. See generally AMNESTY INTERNATIONAL, CHILD SOLDIERS: ONE OF THE WORST ABUSES OF CHILD LABOR (1999) (reviewing international legal prohibitions on utilization of child soldiers); ILENE COHN \& GUY GOODWIN, CHILD SOLDIERS: THE ROLE OF CHILDREN IN ARMED CONFLICT 55-72 (1994). 
recognize those crimes as giving rise to universal jurisdiction. ${ }^{73}$ If this proposed extension of universal jurisdiction meets with broad consent, then the law will change accordingly and this particular flaw in a universal-jurisdiction theory of ICC jurisdiction will, in time, be eliminated. Even if all that comes to pass, however, a theory of delegated universal jurisdiction would nevertheless face a much more fundamental obstacle.

The fundamental problem with reliance on universal jurisdiction as a basis for ICC jurisdiction over non-party nationals turns on the question whether universal jurisdiction may be delegated to an international court. The proposition that the universal jurisdiction of states is delegable to an international entity warrants examination.

1. The Significance of Delegation. The delegation of states' universal jurisdiction to an international court would fundamentally alter the consequences of that jurisdiction. The exercise of delegated universal jurisdiction by an international court would have very different implications, involving a different set of state interests, than would the exercise of universal jurisdiction by a state. Because the consequences of universal jurisdiction would be fundamentally transformed by the delegation itself, consent to the universal jurisdiction of states should not be considered equivalent to consent to the delegation of universal jurisdiction to an international court.

Customary international law evolves as a reflection of the consent or acquiescence of states over time. Because consent to universal jurisdiction exercised by states is not equivalent to consent to delegated universal jurisdiction exercised by an international court, the customary law affirming the universal jurisdiction of states cannot be considered equivalent to customary law affirming the delegability of that jurisdiction to an international court.

There are sound reasons for which a state, even while accepting universal jurisdiction, might wish to reject the delegation of such jurisdiction for exercise by an international court. A state might reject compulsory third-party adjudication before the ICC in order to retain the discretion to address interstatedispute type cases through bilateral relations, even while recognizing the possibility that those bilateral relations might in some cases entail the prosecution of that state's national in another state's courts under universal jurisdiction. The reasons for which states might prefer bilateral relations to third-party adjudication in interstate disputes involving international criminal law are essentially the same as the reasons, discussed earlier, for which states are generally reluctant to submit their interstate disputes to third-party adjudication.

As observed earlier, while the most blatant instances of genocide, war crimes, or crimes against humanity leave nothing to dispute or negotiate, many cases involving allegations of genocide, crimes against humanity, or, especially, war crimes concern issues of unsettled law or ambiguous facts, or both. In such

73. The status of the ICC Treaty as generating customary law will be considered below. See infra Part IVB. 
cases, states may have legitimate reasons for preferring mechanisms other than binding adjudication.

States value the advantages that diplomatic methods of dispute settlement often afford. Particularly where an interstate dispute concerns an area of unsettled law, litigation may entail more risk than states can be expected to accept. If the subject matter is important and the law is unsettled, allowing a third party to, in effect, decide the binding law of the matter is a very perilous course of action. Cases involving highly contested facts also entail obvious risks. States may, therefore, perceive a number of drawbacks associated with compulsory adjudication before the ICC.

First, compromise outcomes of various sorts may be desirable in interstatedispute type cases, especially in circumstances where the law or the facts are ambiguous. But compromise outcomes are unlikely to emerge from adjudicated rather than negotiated resolutions.

Second, states would have reason to be more concerned about the political impact of adjudications before an international court than before an individual states' courts. An even-remotely successful international court will have significant prestige and authority. The political repercussions of such a court's determining that a state's acts or policies were unlawful would be substantial indeed, and categorically different from the repercussion of the same verdict rendered by a national court. If a guilty verdict were passed by a national court in an official-acts case, the matter would remain a disagreement among equals, one state maintaining that an unlawful act had been committed, the other disputing its occurrence or defending its lawfulness. By contrast, were the ICC to pronounce an official act to constitute a crime, the decision would bear an authoritative weight and resulting political impact of a categorically different nature. The special political impact of ICC decisions will itself create heightened risks for states. It may also create situations in which states will be put to a choice of either revealing sensitive data as defense evidence or withholding that evidence and thereby risking severe political costs in case of a guilty verdict.

A third matter that may be of substantial concern to states is the role of an international criminal court in shaping the law. Because the decisions of an international court will tend to be more authoritative than would those of any individual state's courts, an international court would have the power to create international law in a manner disproportionate to that of any state. This may be more law-making power than some states are comfortable granting to one international institution, especially in sensitive areas involving military activities and international security.

Because the law of genocide, war crimes, and crimes against humanity ${ }^{74}$ is still very much in formation, the issue of law-making power is particularly important in this context. Controversial and politically significant issues remain open, and major new questions continue to emerge. Reflecting the developing

74. I leave aside the crime of aggression, which is not, for the time being, within the effective jurisdiction of the ICC. See supra note 2. 
state of the law in this field, the appellate chamber of the International Criminal Tribunals for the former Yugoslavia and Rwanda ("ICTY/R") has on more than one occasion reversed a trial chamber decision on a basic point of law.

Developments in the Tadic case illustrate the point. The "grave breaches" provisions of the Geneva Conventions of 1949 provide for universal jurisdiction over certain crimes when those crimes are committed in international armed conflicts. ${ }^{75}$ Article 2 of the Statute of the International Criminal Tribunal for the Former Yugoslavia ("ICTY") provides that "[t]he international tribunal shall have the power to prosecute persons committing or ordering to be committed grave breaches of the Geneva Conventions of 12 August 1949, namely the following acts ...." ${ }^{\prime 76}$ The ICTY trial chamber held in Tadic that, when acts defined as grave breaches in the Geneva Conventions are committed against persons or property categorized as protected under the Geneva Conventions, such conduct may be prosecuted before the ICTY regardless of whether the acts were committed in an international armed conflict. According to the trial chamber, Article 2 of the ICTY Statute

has been so drafted as to be self-contained rather than referential, save for the identification of the victims of enumerated acts; that identification and that alone involves going to the Conventions themselves for the definition of "persons or property protected".... 2....

$[T]$ he requirement of international conflict does not appear on the face of Article

[T]here is no ground for treating Article 2 as in effect importing into the Statute the whole of the terms of the Conventions, including the reference in common Article 2 of the Geneva Convention[s] to international conflicts. . . .

The ICTY appellate chamber rejected that holding, stating:

With all due respect, the Trial Chamber's reasoning is based on a misconception of the grave breaches provisions and the extent of their incorporation into the Statute of the International Tribunal... The international armed conflict requirement was a necessary limitation on the grave breaches system in light of the intrusion on state sovereignty that such mandatory universal jurisdiction represents. State parties to the 1949 Geneva conventions did not want to give other states jurisdiction over serious violations of international humanitarian law committed in their internal armed conflicts-at least not the mandatory universal jurisdiction involved in the grave breaches system.

75. See Geneva Convention for the Amelioration of the Condition of the Wounded and Sick in Armed Forces in the Field, Aug. 12, 1949, arts. 2, 49, 50,6 U.S.T. 311475 U.N.T.S 31; Geneva Convention for the Amelioration of the Condition of the Wounded, Sick and Shipwrecked Members of the Armed Forces at Sea, Aug. 12, 1949, arts. 2, 50, 51, 6 U.S.T. 321775 U.N.T.S 85; Geneva Convention III Relative to the Treatment of Prisoners of War, Aug. 12, 1949, arts. 2, 129, 130, 75 U.N.T.S 135; Geneva Convention IV Relative to the Protection of Civilian Persons in Time of War, Aug. 12, 1949, arts. 2, 146, 147, 75 U.N.T.S 287.

76. Statute of the International Criminal Tribunal for the Prosecution of Persons Responsible for Serious Violations of International Humanitarian Law Committed in the Territory of the Former Yugoslavia Since 1991, in Report of the Secretary-General Pursuant to Paragraph 2 of Security Council Resolution 808, Annex, art. 2, U.N. Doc. S/25704 (1993).

77. Prosecutor v. Dusko Tadic, Decision on the Defence Motion on Jurisdiction, Case No. IT-94-1T, decision of Aug. 10, 1995, II 4 49-51. 
[T] he Trial Chamber has misinterpreted the reference to the Geneva Conventions contained in the sentence of Article 2: "persons or property protected under the provisions of the relevant Geneva Conventions." . . Clearly, these provisions of the Geneva Conventions apply to persons or objects protected only to the extent that they are caught up in an international armed conflict. ...

The appellate chamber thus reversed the trial court on a very basic question of international criminal law. The trial chamber was prepared to treat the international-conflict requirement as merely incidental to the Geneva Conventions' definition of grave breaches. The appellate chamber ruled that the trial court's holding misconceived the limited nature of the consent to universal jurisdiction given by the states parties to the Geneva Conventions. Such issues, of great significance going to the very basis of the legitimacy of international criminal law, are only now in the process of being decided, as the Tadic appeal demonstrates.

Appellate reversals of trial chamber decisions on major legal issues such as that in the Tadic case and in other cases before the ICTY $/ \mathrm{R}^{79}$ indicate that this is an area of law in formation and in which there will be disagreements among experts about the content of the law. It is therefore likely that one state might take a different view of the legality of a particular act or policy than would another state or an international court.

There are, of course, disagreements about the content of the law in domestic settings; and appellate courts reverse trial chambers' decisions in domestic judi-

78. Prosecutor v. Dusko Tadic, Decision on the Defence Motion for Interlocutory Appeal on Jurisdiction, Case No. IT-94-1-AR72, decision of Oct. 2, 1995, II II 80-83 [hereinafter Tadic Appeal].

79. Another example of the ICTY/R's addressing major and unsettled legal questions through the process of trial and appeal concerns a defendant's right to counsel. Jean-Paul Akayesu was an indigent defendant indicted for genocide and other crimes before the International Criminal Tribunal for Rwanda ("ICTR"). See Prosecutor v. Jean-Paul Akayesu, Case No. ICTR-96-4-T, Trial Chamber decision of Sept. 2, 1998. After dismissing a number of lawyers assigned for his defense, Akayesu decided that he wanted the Canadian lawyer, Jean Philpot, to represent him. Prosecutor v. Jean-Paul Akayesu, Case No. ICTR-96-4-T, Appeals Chamber Decision Relating to the Assignment of Counsel, decision of July 27, 1999. At Akayesu's request, Philpot was placed on the list of available counsel that is maintained by the ICTR registrar, see id., but the registrar subsequently refused Akayesu's request to be represented by Philpot. See id. The registrar's refusal was upheld by the ICTR trial chamber on the ground that too great a proportion of the counsel appointed by the ICTR were French or Canadian. See At a Genocide Trial, French is a Handicap, N.Y. TIMES, Feb. 19, 1999, at A11. That trial chamber decision was reversed on appeal in a very narrow opinion tied closely to the facts of the case:

$[\mathrm{T}]$ he practice of the Tribunal has been to provide a list of approved counsel from which an accused may choose.... Mr. Philpot was included in this list by the Registrar upon the insistence of the Appellant that he desired that Mr. Philpot be assigned to him ... . [T] he Registrar thereby gave the Appellant a legitimate expectation that Mr. Philpot would be assigned to represent him before the Tribunal.

Akeyesu Appeals Chamber Decision, supra, at 3.

By basing its holding narrowly on Akayesu's legitimate expectations in the particular circumstances of the case, the appellate chamber chose not to address the broad issues that the case raised regarding the right to defense counsel and, in particular, the proper balancing of the defendant's interest in choice of counsel with the United Nations' interest in geographical representativeness of its personnel. These broader implications of the case were addressed in a number of petitions submitted to the Appellate Chamber. See, e.g., Petition for the Intervention as Amicus Curiae, of the International Criminal Defense Attorneys Association, filed on April 28, 1999. The Akayesu Defense Counsel case thus represents another major question in international criminal law which has come before the ICTY/R, but in this case, the substance of the matter remains to be addressed. 
cial systems. This is precisely what makes the structure of the judiciary a crucial feature of states' constitutional designs. What is at issue in the ICC context is whether the judicial structure being proposed-which will then play an inevitably influential role in shaping the law-is acceptable to those who have been asked to join in constituting and accepting the jurisdiction of that judicial power.

The law developed by the ICC will not be susceptible to revision or modification through any legislative process. In municipal justice systems, if the court gets it wrong, the legislature provides a safety valve. There is no such recourse relative to the ICC. ${ }^{80}$ States may have legitimate concerns about the compulsory jurisdiction of such a court; they may not see fit to have an international tribunal in effect legislate international law in areas where the law is relatively undeveloped. States might have sound reasons for preferring to retain more direct control, diffused among many states, over the shaping of international law in this critical field rather than to relegate a substantial proportion of that control to a single international entity.

States are keenly interested that the law in this field should develop in directions that are consistent with their views of international relations, with the extent and nature of their military engagements, as well as with their visions of what would provide the greatest justice and deterrence value. The development of international criminal law, like the development of other areas of international law, is a process of state consent, agreement, and acquiescence. Its development is, in that respect, a series of more or less directly negotiated outcomes in an incremental process. A state might be concerned about granting jurisdiction to an international court that inevitably would have great influence, disproportionate to that of any state, in the formation of that body of law. ${ }^{81}$

In the ways just described, the consequences and implications of ICC jurisdiction are materially different from those of national jurisdiction. These differences are sufficiently significant so that the customary international law of universal jurisdiction should not be quickly presumed to entail the delegability of that jurisdiction from states to an international court. Because different states' interests are affected by the two forms of jurisdiction, consent to or acquiescence in one is not equivalent to consent to or acquiescence in the other.

80. The Assembly of States Parties, by the terms of the ICC Treaty, will provide only a rather minimal form of oversight of the Court's operations. See ICC Treaty, supra note 1, art. 112 (establishing an Assembly of States Parties with oversight functions relative to the ICC).

81. States may reasonably have significant concerns about ICC jurisdiction not only with regard to official-acts cases but also in relation to cases of the individual-culpability type. In individualculpability cases, the concerns will relate primarily to diplomatic protection. If a state finds it necessary to provide diplomatic protection to ensure just treatment of a national who is facing prosecution, that state may confront significant disadvantages in interacting with the ICC rather than with another state. In a sense, the need to provide diplomatic protection to ensure just treatment of a national in an individual-culpability case transforms that case, or at least the aspect of it involving the diplomaticprotection issue, into a dispute between the state of the defendant's nationality and the prosecuting authority. Where that dispute is with a state, bilateral diplomatic methods may be employed. Where that authority is an international court, the nature of the dispute resolution process would be entirely different. Indeed, no process for the resolution of such disputes with the ICC has been articulated. 
The arguments, frequently offered as a response to concerns about ICC jurisdiction, that the ICC would address only very grave crimes, that the ICC prosecutor would be a person of distinction and fine judgment, and that the ICC is not intended to interfere in the affairs of basically law abiding states, do not adequately respond to the fundamental concerns that states may have. Reactions to the NATO intervention in Kosovo illustrate that the arguments offered are beside the point.

Some NATO military actions during the armed conflict in Kosovo were characterized as war crimes by a number of distinguished international lawyers and political actors. ${ }^{82}$ South African Minister of Education (formerly Minister of Water Affairs and Forestry) Kader Asmal stated in July 1999 that NATO's "bombing of water resources in [the Kosovo campaign] is a war crime." May 10, 1999, international law professor Ian Brownlie argued on behalf of the Federal Republic of Yugoslavia before the ICJ that the NATO action was in violation of international law for reasons including "the unlawful modalities of the aerial bombardment." On the same day, lawyers from several countries filed a complaint with the ICTY prosecutor against NATO officials and leaders of NATO member states for alleged war crimes committed in NATO's armed intervention in Yugoslavia. ${ }^{85}$ ICTY prosecutor Louise Arbour subsequently indicated that she would investigate those charges. ${ }^{86}$ All of these statements were made by persons of judgment and distinction. Each was a person who would be a credible candidate for office within the ICC. One need not assume that the ICC would act unreasonably or abusively to envision that any state's action, viewed by that state as lawful, could someday become the subject of an ICC prosecution.

There is an aspect of some of the arguments favoring prosecutions for NATO actions that bears particular notice in this respect. Professor Michael Byers, for example, suggested that, if indeed war crimes had been committed in the NATO action, it would be particularly important to prosecute those crimes in order to demonstrate the evenhandedness of the ICTY. ${ }^{87}$ Such an approach would be consistent with prior ICTY prosecutorial strategy in which, for example, one stated purpose for indictment of a number of Croats at the particular time they were indicted was to dispel Serbian suspicions that the ICTY was

82. I leave aside here the legality of the NATO military intervention itself because the crime of aggression is not currently within effective ICC jurisdiction as framed by the ICC Treaty. See supra note 2 .

83. Alex Kirby, Kosovo Waterways Bombing a "War Crime" (visited Mar. 22, 2000) $<$ http://news2.thls.bbc.co.uk/hi/english/world/newsid_394000/394326.stm>.

84. Ian Brownlie, Co-Agent for the Federal Republic of Yugoslavia, Remarks before the ICJ in the Case Concerning Legality of the Use of Force (May 10, 1999) (on file with author).

85. See Bruce Zagaris, Complaint Before War Crimes Tribunal Charges NATO Leaders with War Crimes, 15 INT'L L. ENFORCEMENT REP. 249 (1999).

86. See Burden of Proof (CNN television broadcast, June 1, 1999). 1999).

87. Interview with Michael Byers, The World Tonight (BBC Radio 4 radio broadcast, May 28, 
anti-Serb. $^{88}$ If this view regarding the place of "evenhandedness" in international prosecutorial strategy is applied by the ICC, then it could become even more likely that the actions of non-"rogue" states would become the subject of ICC prosecutions.

Thus, even if the ICC will prosecute only grave crimes, will have a distinguished prosecutor with fine judgment, and will not interfere in the affairs of basically law abiding states, this does not mean that the actions of any given state could never realistically become the subject of ICC prosecutions. Therefore, the question whether ICC jurisdiction is acceptable to a given state must be evaluated on the assumption that ICC jurisdiction may actually be applied.

We have seen that the consequences of universal jurisdiction exercised by a state are significantly different from the consequences of delegated universal jurisdiction exercised by an international court. For that reason, consent to states' exercise of universal jurisdiction is not equivalent to consent to the delegation of universal jurisdiction to an international court. By extension, customary law supporting the exercise of universal jurisdiction by states is not equivalent to customary law supporting the delegation of states' universal jurisdiction to an international court. Therefore, we may not simply assume that states' universal jurisdiction may be delegated to an international court as a matter of customary international law. Rather, the question requires analysis.

2. The Content of Custom. As we have seen, there are comprehensible and even good reasons for which a state might object to the delegation of states' universal jurisdiction to the ICC. We turn now to a closer examination of the legal status of such objections.

Universal jurisdiction arises as a matter of customary international law. ${ }^{89}$ If, by custom, universal jurisdiction were delegable to an international court, then states would be obliged to accept such delegation and, by extension, to accept ICC jurisdiction over non-party nationals. If, however, delegation of universal jurisdiction to an international court would constitute an innovation beyond the customary meaning of universal jurisdiction, then the legal status of jurisdiction based on such delegation would remain to be determined. The initial question, then, is whether the customary international law of universal jurisdiction, as it has developed through state practice and opinio juris, entails the possibility of delegation to an international court.

State practice relating to the exercise of criminal jurisdiction by an international court has been limited. The ICTY/R are believed by some to found their jurisdiction on the delegated universal jurisdiction of states. ${ }^{90}$ However, as the

88. Conversation of author with Richard Goldstone, then-Prosecutor, ICTY/R, in Brussels, Belgium (July 20, 1996).

89. Cf. infra Part IVA (regarding the notion of universal jurisdiction created by treaty).

90. See, e.g., REVISED REPORT OF THE WORKING GROUP ON THE DRAFT STATUTE FOR AN INTERNATIONAL CRIMINAL COURT IIII 72-73, U.N Doc. A/CN.4/L.490 and Add.1 (1993); Yoram Dinstein, The Universality Principle and War Crimes, in THE LAW OF ARMED CONFLICT: INTO THE NEXT MiLlENIUM 17-37 (Michael Schmitt \& Leslie Green eds., 1998). 
ICTY/R are products of U.N. Security Council action under Chapter VII of the U.N. Charter, ${ }^{91}$ the tribunals' jurisdiction is more properly viewed as arising from the powers of the Security Council to take such steps as are required to restore or maintain international peace and security. In responding to jurisdictional challenges going to the legitimacy of the establishment of the ICTY and ICTR, each tribunal has responded by affirming the power of the Security Council, acting under Chapter VII, to establish a judicial tribunal as an instrument for the maintenance of international peace and security and has cited that Security Council power as forming the jurisdictional foundation of the tribunal. ${ }^{92}$ Neither tribunal has invoked delegated universal jurisdiction or any other form of universal jurisdiction as the basis of its jurisdiction. ${ }^{93}$

91. See U.N. S.C. Res. 827, U.N. Doc. S/Res. 827 (1993) and U.N. S.C. Res. 955, U.N. SCOR, 3453d mtg. (1994) (specifying that, in establishing the ICTY and ICTR, respectively, the Security Council was acting under Chapter VII).

92. See Tadic Appeal, supra note 78, at 5-24; Prosecutor v. Joseph Kanyabashi, ICTR, Decision on the Defence Motion on Jurisdiction, Case No. ICTR-96-15-T, June 18, 1997, IIII 7-29.

In April 1999, the Federal Republic of Yugoslavia (FRY) brought suit before the ICJ accusing ten NATO countries of violating international obligations to refrain from the use of force against another state. See ICJ, Press Communiqué 99/39, July 2, 1999 (visited Mar. 22, 2000) <http://www.icj-cij.org>. Several of those NATO respondents, including the United States, challenged the FRY's right to bring suit under the ICJ's optional-clause jurisdiction on the basis that the FRY was not a member of the United Nations. See, e.g., Legality of Use of Force (Yugo. v. Can.), Request for the Indication of Provisional Measures, 1999 I.C.J. Public Sitting CR99/16 II 10 (statement of Philippe Kirsch, Agent of Canada) (visited Mar. 22, 2000), <http://www.icj-cij.org/icj/idocket/iyall/iyall_iyca_icr9916_19990510.htlm>. To support the claim that the FRY was not a U.N. member, the respondents made reference to U.N. Security Council Resolution 777 of 1992 and U.N. General Assembly Resolution 47/1 of 1992. See id. If 11. The FRY argued, in response, that those resolutions excluded the FRY only from occupying its seat in the General Assembly but not from other participation in the U.N. system. The ICJ declined the FRY's request for provisional measures in the case, but did so on other grounds without addressing the U.N-membership issue. See ICJ, Press Communiqué, supra.

These circumstances raise the question of what authority the ICTY has in the FRY in light of the fact that the ICTY's jurisdiction and other authority arises from U.N. Security Council action. If the FRY is not a U.N. member (and already was not a member as of 1992 when the two relevant U.N. resolutions were adopted), then, one could argue, the ICTY (which was established in 1993) has no powers in the FRY and no jurisdiction over FRY nationals.

There are a number of appropriate responses to this set of circumstances. First, we must recognize that the status of the FRY relative to the United Nations is not settled. If the FRY's own position on this matter prevails, then the FRY is indeed a U.N. member and, perforce, bound by the Security Council action establishing the ICTY (notwithstanding the FRY's own protests, on other grounds, to ICTY jurisdiction). See Letter from the Charge d'affaires, a.i., of the Permanent Mission of Yugoslavia to the United Nations Addressed to the Secretary General of the United Nations (May 19, 1993) (U.N. Doc. A/48/170-S/25801 (1993)). Given that the FRY's mission to the U.N. has continued to exist and to receive official U.N. communications, that the FRY flag has continued to fly outside U.N. headquarters, and other indicia of U.N. membership, it is not entirely farfetched that the FRY would be found to hold membership.

If on the other hand, the FRY were found to be a non-member of the U.N., then the question whether the U.N. Charter is binding on non-parties would be directly posed. Regarding this debate, see infra text accompanying notes 150-167. If the charter were found to be binding in a robust way on non-parties, then the ICTY would maintain its powers in the FRY. If, however, the charter were found not to be binding on non-members in the relevant respects, then this would have far-reaching and profound consequences, quite possibly among them the loss of the ICTY's powers within the FRY and jurisdiction over FRY nationals.

93. By contrast, the ICTY has made reference to the principles underlying universal jurisdiction in justifying the primacy of the ICTY over national courts (the concept of primacy is not adopted by the ICC Treaty) and in justifying prosecution of defendants before the international forum rather than be- 
The other international criminal tribunals that some view as precedents for the collective exercise of universal jurisdiction are the International Military Tribunal ("Nuremberg tribunal") and the International Military Tribunal for the Far East ("Tokyo tribunal") established in the aftermath of World War II ("WWII"). ${ }^{94}$ But, in fact, neither the Nuremberg nor the Tokyo tribunal based its competence on the collective exercise of universal jurisdiction. Rather, the Nuremberg and Tokyo tribunals each, in different ways, based their jurisdiction on the consent of the state of nationality of the defendants.

This is not to say that those WWII tribunals were right to have based their jurisdiction on the consent of the defendants' states of nationality. Strong arguments have been made that the claimed jurisdictional basis was flawed by the coerced nature of the consent. ${ }^{95}$ But, even if the jurisdiction of those tribunals were flawed by the coerced nature of the consent, that would mean nothing more than that the jurisdiction was flawed. It would not imply that the tribunals' jurisdiction had rested on some other basis, such as collective exercise of universal jurisdiction.

In the case of the Tokyo tribunal, the Japanese government (which, at least formally, retained sovereign power in Japan after the war) acceded, in the Instrument of Surrender ${ }^{96}$ to prosecution of Japanese nationals before the International Military Tribunal for the Far East. The Instrument of Surrender states that the Japanese government accepts the provisions set forth in the Potsdam Declaration of July 26, $1945,{ }^{97}$ and agrees to "take whatever action may be required by the Supreme Commander for the Allied Powers or by any other designated representative of the Allied Powers for the purpose of giving effect to that Declaration." 98 The Potsdam Declaration, in turn, provides that "stern justice shall be meted out to all war criminals." states that the terms of the Cairo Declaration shall be carried out. ${ }^{100}$ The Cairo Declaration included the statement that " $[\mathrm{t}]$ he ... allies are fighting this war to restrain and punish the aggression of Japan." ${ }^{101}$ The primacy of the Instrument of Surrender, read together with the two Declarations, in constituting Japan's

fore their "natural" (national) fora. See Tadic Appeal, supra note 78, at 32-33 (primacy), 34 ("natural forum"). The ICTY has not, however, stated or in any way implied that universal jurisdiction formed the basis for its jurisdiction.

94. See, e.g., Christopher Greenwood, The Prosecution of War Crimes in the Former Yugoslavia, 26 BRACTON L.J. 13, 16 (1994) (Nuremberg tribunal).

95. See, e.g., R. JOHN PRITCHARD, AN OVERVIEW OF THE HISTORICAL IMPORTANCE OF THE TOKYO WAR TRIAL 8-10 (1987) [hereinafter PRITCHARD, AN OVERVIEW] (regarding Tokyo); $c f$. Hans Kelsen, The Legal Status of Germany According to the Declaration of Berlin, 39 AM. J. INT'L L. 518,523 (1945) (noting that the Allies did not afford German citizens political rights and representation).

96. Sept. 2, 1945, 3 Bevans 1251.

97. 3 Bevans 1204; see Instrument of Surrender, supra note 96, at 1251.

98. Instrument of Surrender, supra note 96 , at 1252.

99. Potsdam Declaration, supra note 97, at 1205, II 10.

100. See id. II 8 .

101. Communiqué, First Cairo Conference, Dec. 1, 1943, 3 Bevans 858; see also PRITCHARD, supra note 95, at 9; R. John Pritchard, The International Military Tribunal for the Far East and Its Contemporary Resonances, 149 MIL. L. REV. 25, 27-28 (1995) [hereinafter, Pritchard, The International Tribunal]. 
consent and, thereby, forming the jurisdictional basis for the Tokyo tribunal, is affirmed both in the Tokyo tribunal's charter and in its judgment. ${ }^{102}$

With regard to the Nuremberg tribunal, the story is more complex. The four Allied states that established the Nuremberg tribunal had taken on supreme authority in Germany. As stated in the Berlin Declaration of June 5, 1945

[t]he Governments of the United States of America, The Union of Soviet Socialist Republics and the United Kingdom, and the Provisional Government of the French Republic, hereby assume supreme authority with respect to Germany, including all the powers possessed by the German Government, the High Command and any state, municipal, or local government or authority. ${ }^{103}$

In that position, the Allies exercised judicial and all other powers of sovereignty in Germany. At a minimum, the Allies, acting in their capacity as the effective German sovereign, consented to the prosecution of German nationals at the Nuremberg tribunal. A more robust, and perhaps more accurate, reading would be that the Nuremberg tribunal prosecutions were actually an exercise of national jurisdiction by the effective German sovereign, the Allies. In either case, the effective German sovereign consented to the prosecutions.

One may debate whether the Allies were the German sovereign in 1945 or merely stood in loco sovereigntis. Clearly, the Allies stood in a position essentially different from that of mere occupiers. ${ }^{104}$ There has been no disagreement

102. See PRITCHARD, AN OVERVIEW, supra note 95, at 9 n.16 (citing Proceedings, Vol. 20; Judgment, T.48415-19, and Annex A-1 - A-5); see also In re Yamashita, 327 U.S. 4, 13 (1945) ("Japan, by her acceptance of the Potsdam Declaration and her surrender, has acquiesced in the trials of those guilty of violations of the law of war."); John Pritchard, The International Military Tribunal for the Far East and its Contemporary Resonances: A General Preface to the Collection, in THE TOKYO MAJOR WAR CRIMES TRIAL xxxi (J. Pritchard ed., 1998).

103. Berlin Declaration, June 5, 1945, 60 Stat. 1649, 1650; see also Agreement Between the Governments of the United States of America and the Union of Soviet Socialist Republics and the United Kingdom and the Provisional Government of the French Republic on Certain Additional Requirements to be Imposed on Germany, Sept. 20, 1945, 3 Bevans 1254 (delineating further the powers to be exercised by the Allies including prosecutions for war crimes).

104. As Fritz Mann reasoned at that time,

to place the City of Koenigsberg and the territories east of the Oder-Neisse line under Soviet and Polish administration respectively far exceed the limits within which a mere belligerent occupant could act, no belligerent occupant could withdraw diplomatic missions or require "German authorities and all persons in Germany" to hand over all gold, silver and platinum, or acquire the right to have placed "at the unrestricted disposal of the Allied Representatives" the entire German shipping and the whole of the German inland transport system. And if one looks at the legislation of the Control Council, one finds Law No. 4 about the reorganisation of the German judicial system ....

The Allies' failure to exercise the qualified rights of a belligerent occupant seems to be undeniable.... The material question is why the Allies have an internationally recognisable right to behave otherwise than as belligerent occupants. ...

Although neither the end of hostilities nor the unconditional surrender nor the disappearance of a central government could, in themselves, have entitled the Allied Governments to adopt an attitude other than that of a belligerent occupant, it is, in the peculiar situation of Germany in 1945, the co-existence of these three facts which provides an internationally recognisable justification for Allied action. The rules relating to belligerent occupation seek to establish a compromise between military necessities and the interests of the inhabitants.... They expect, from both sides, a standard of conduct which becomes impracticable when every single activity of the occupied state expresses a doctrine the eradication of which is the very 
as to whether the Allies' position in post-war Germany exceeded the traditional bounds of occupation. Rather, debate focused on whether the Allies were actually the sovereign(s) in post-war Germany or only stood in the place of the sovereign. Fritz Mann took the position that the Allies, while not having assumed territorial sovereignty, nevertheless assumed governmental sovereignty and, thus, occupied the status of the Government of Germany. As he wrote,

from the point of view of international law Germany is a dependent state.... The position of the Allied Governments probably is that they exercise what certain publicists have described as co-imperium. While in the case of a condominium a community of states has sovereignty over a territory belonging to them jointly, a co-imperium exists, if several states jointly exercise jurisdiction or governmental functions and powers in territory belonging to another state....

Georg Schwarzenberger argued that the Allies were co-sovereigns of Germany and that they conducted the Nuremberg tribunal in that capacity. In his words,

by deballatio, [the Allies] became the joint sovereigns of Germany. Little importance need, therefore, be attached to the circumstance that the joint sovereigns exercised their jurisdiction as the fountain of law and justice in Germany by an international treaty; for this mode of co-ordinating their sovereign wills is not so much determined by the object of their joint deliberations as by the character of the joint sovereigns as four distinct subjects of international law. As the Tribunal stated in its judgment, there would have been little doubt regarding the municipal character of the Tribunal if one state alone had overrun Germany and established such a tribunal, instead of four victorious Powers combining their efforts towards the same end: "The Signatory Power created this Tribunal, defined the law it was to administer, and made regulations for the proper conduct of the Trial. In doing so, they have done together what any of them might have done singly." [Citing the Nuremberg Judgment, infra note 111.] ... Furthermore, in accordance with Article 29 of the Tribunal's Charter, the right of pardon rests with the Control Council for Germany. In substance, therefore, the Tribunal is a municipal tribunal of extraordinary jurisdiction which the four Contracting Powers share in common. ${ }^{106}$

Hans Kelsen also took the view that the Allies had the right to conduct the Nuremberg tribunal based on their position as German sovereign. As he said,

the criminal prosecution of Germans for illegal acts of their state could have been based on national law, enacted for this purpose by the competent authorities. These authorities were the four occupant powers exercising their joint sovereignty in a condominium over the territory and the population of subjugated Germany through the Control Council as the legitimate successor of the last German Government. ${ }^{107}$

aim of the war... . No German Government could have been formed to co-operate with a mere belligerent occupant. If the Allies had assumed only the role of belligerent occupants, they and the United Nations in whose interests they act, could not achieve their war aims, which go far beyond military victory; indeed, they would have failed to fulfil their duty and historic mission. It is the unique character of the circumstances which required and sanctioned a unique solution, a new departure.

Fritz A. Mann, The Present Legal Status of Germany, 1 INT’L L. Q. 314, 321-23 (1947).

105. Mann, supra note 104, at 330.

106. Georg Schwarzenberger, The Problem of an International Criminal Law, 3 CURRENT LEGAL PROBS. 263, 290, 291 (1950); see also Georg Schwarzenberger, The Judgment of Nuremberg, 21 TUL. L. REV. 329, 334-35 (1947).

107. Hans Kelsen, Will the Judgment in the Nuremberg Trial Constitute a Precedent in International Law?, 1 INT'L L. Q. 153, 167 (1947). Kelsen, however, went on to reason (in a manner of particular in- 
We may conclude, at a minimum, that the Nuremberg tribunal, having acted with the consent of the Allies, acted with the consent of the effective sovereign of the defendants' state of nationality. It may also be that, beyond merely consenting to the Nuremberg tribunal prosecutions, the Allies actually created the tribunal and conducted those prosecutions in their capacity as effective sovereign. Indeed, this is the view reflected in the Judgment of the Nuremberg tribunal, which states: "[T] he making of the Charter [establishing the Nuremberg tribunal] was the exercise of the sovereign legislative power by the countries to which the German Reich unconditionally surrendered; and the undoubted right of these countries to legislate for the occupied territories has been recognized by the civilized world." 108

The jurisdictional basis of the Nuremberg tribunal was not delineated, in the tribunal's charter or judgment, with greater precision. While the language quoted above is strong evidence that the Nuremberg tribunal based its jurisdiction on the consent of the Allies as effective German sovereign, an alternative theory, that the Nuremberg tribunal based its jurisdiction on universal jurisdiction, has attained some currency over the years. The passage from the U.N. Secretary General's 1949 Report on the Nuremberg tribunal, from which this theory may have garnered some of its force, begins by quoting the same sentence from the Nuremberg judgment quoted immediately above. It then goes on to say:

In this statement the Court refers to the particular legal situation arising out of the unconditional surrender of Germany in May 1945, and the declaration issued in Berlin on 5 June 1945, by the four Allied states, signatories of the London Agreement. By this declaration the said countries assumed supreme authority with respect to Germany, including all the powers possessed by the German Government, the High Command and any state, municipal or local government or authority. The Court apparently held that in virtue of these acts the sovereignty of Germany had passed into the hands of the four states and that these countries thereby were authorized under international law to establish the Tribunal and invest it with the power to try and punish the major German war criminals.

The Court, however, also indicated another basis for its jurisdiction, a basis of more general scope. "The Signatory Powers" [the Tribunal said], "created this Tribunal, defined the law it was to administer, and made regulations for the proper conduct of the trial. In doing so, they have done together what any one of them might have done singly; for it is not to be doubted that any nation has the right thus to set up special courts to administer law." The statement is far from clear, but, with some hesitation, the following alternative interpretations may be offered. It is possible that the Court meant that the several signatory Powers had jurisdiction over the crimes defined in the Charter because these crimes threatened the security of each of them. The Court may, in other words, have intended to assimilate the said crimes, in regard to jurisdiction, to such offences as the counterfeiting of currency. On the other hand, it is also possible and perhaps more probable, that the Court considered the crimes

terest for our question of ICC jurisdiction over non-party nationals) that if, as he believed was the case, the Allies did not exercise jurisdiction based on their sovereignty in Germany but rather attempted to represent the Nuremberg tribunal as an international tribunal, then its jurisdiction was illegitimate precisely because it lacked the consent of non-parties to the London Agreement, the treaty that formed the basis of the Nuremberg tribunal's jurisdiction. See id. at 168.

108. Judgment of the International Military Tribunal, Sept. 30, 1946, reprinted in RICHARD A. FALK ET AL., CRIMES OF WAR 96 (1971). 
under the Charter to be, as international crimes, subject to the jurisdiction of every state. The case of piracy would then be the appropriate parallel. This interpretation seems to be supported by the fact that the Court affirmed that the signatory Powers in creating the Tribunal had made use of a right belonging to any nation. But it must be conceded, at the same time, that the phrase "right thus to set up special courts to administer law" is too vague to admit of definite conclusions. ${ }^{109}$

The Secretary General was right to be wary of drawing, from that passage in the Nuremberg judgment, the conclusion that the Nuremberg tribunal's jurisdiction was based on the protective principle (the reference to counterfeiting) or on the universality principle (the reference to piracy). Rather, the assertion in the Nuremberg Judgment that, in establishing the Nuremberg tribunal, the Allies had "done together what any one of them might have done singly" is equally applicable to a sovereign-consent theory as to a universal-jurisdiction theory of that tribunal's jurisdiction. Indeed, read together with the passage of the judgment which states that "the making of the Charter was the exercise of the sovereign legislative power by the countries to which the German Reich unconditionally surrendered," 111 the meaning seems more consistent with the view that the jurisdiction of the Nuremberg tribunal rested on the effective sovereign powers of the Allies to prosecute or consent to the prosecution of German nationals.

These considerations have not precluded the occasional assertion that the Nuremberg tribunal rested its competence on the collective exercise of universal jurisdiction. For example, the U.N. Commission of Experts on the former Yugoslavia made the claim that,

states may choose to combine their jurisdictions under the universality principle and vest this combined jurisdiction in an international tribunal. The Nuremberg International Military Tribunal may be said to have derived its jurisdiction from such a combination of the national jurisdiction of the states Parties to the London Agreement setting up that Tribunal. ${ }^{112}$

For this assertion, the commission provided no support whatsoever. In light of the evidence that the Nuremberg tribunal rested its jurisdiction on the exercise of effective sovereignty by the Allies or, at a minimum, on the consent of that effective sovereign, quite substantial evidence, which does not appear to exist, would be required to uphold the commission's claim.

The warranted conclusion appears to be that the jurisdictional basis of the Nuremberg and Tokyo tribunals was not the collective exercise of universal jurisdiction but, rather, the consent of the defendants' states of nationality. With regard to Tokyo, this conclusion is uncontroversial. Regarding Nuremberg, what must be said, at a minimum, is that the tribunal rested its jurisdiction

109. Secretary General of the United Nations, The Charter And Judgment of the NuREMBerg Tribunal: History AND ANAlysis at 80, U.N. Doc. A/CN.4/5, U.N. Sales No. 1949V.7 (1949).

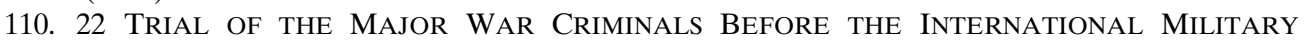
TRIBUnAL 461 (S. Paul A. Joosten ed., 1948).

111. Judgment of the International Military Tribunal, supra note 108, at 96.

112. Interim Report of the Independent Commission of Experts Established Pursuant to Security Council Resolution 780, 1992, II 73, U.N. Doc. S/25274 (1993). 
largely on the fact that the Allies as effective sovereign in post-war Germany consented to the trial of German nationals. ${ }^{113}$

Based on the evidence regarding the jurisdictional bases of the Nuremberg and Tokyo tribunals, those tribunals cannot be relied upon as state practice providing precedent for the delegation of universal jurisdiction to an international court. Nor, as discussed above, do the ICTY/R represent such precedents. None of the four international criminal tribunals that have been established to date, then, provides evidence that the customary international law of universal jurisdiction encompasses the option of delegation to an international criminal court. Nor are there alternative sources of law to be relied on to that effect. ${ }^{114}$

113. One certainly may question whether the Allies should have acted in loco sovereigntis in postwar Germany. Concerns could be raised as to whether the Allies were sufficiently interested in the welfare of the German population to act as the German sovereign. In this regard, see Kelsen, supra note 95, at 523 ("[t]he occupant state ... will not confer upon the former citizens of the occupied state political rights with respect to its own legislative or executive organs ...."). Conducting or consenting to war-crimes prosecutions at the Nuremberg tribunal could be among the points of concern. But the questions of the wisdom and legitimacy of Allied government in post-war Germany need not be resolved in order to acknowledge that precisely such a government did exist. In the position of sovereign or acting sovereign, the Allies fulfilled the role of the government of Germany and, in that capacity, conducted or consented to the prosecution of German nationals by the Nuremberg tribunal.

114. It has occasionally been suggested that the Genocide Convention or the Apartheid Convention provides support for the collective exercise of universal jurisdiction over non-party nationals. Neither convention, however, provides such support.

The Genocide Convention provides for jurisdiction by the territorial state "or by such international penal tribunal as may have jurisdiction with respect to those Contracting Parties as shall have accepted its jurisdiction." Convention on the Prevention and Punishment of the Crime of Genocide, Dec. 9, 1948, art. VI, 78 U.N.T.S. 277 (emphasis added). It thus does not envision that the court would have jurisdiction with respect to non-contracting parties. The international tribunal provision was included in the Genocide Convention essentially for the purpose of avoiding the necessity of amending the Convention's jurisdictional provisions in the future should an international tribunal with competence over genocide be established. See U.N. GAOR 6th Comm., 3d Sess., 97th mtg. at 369, U.N. Doc. A/C.6/SR 61-140 (1948) (Mr. Demesmin, Haiti); U.N. GAOR 6th Comm., 3d Sess., 130th mtg. at 675, U.N. Doc. A/C.6/SR 61-140 (1948) (Mr. DeBeus, Netherlands); U.S. SENATE COMM. ON FOREIGN REL., REPORT ON INT'L CONVENTION ON THE PREVENTION AND PUNISHMENT OF GENOCIDE, 28 I.L.M. 754, 765 (1989). The specifics of creation of such a court and its competence were left open by the Convention. This meant that even states parties to the Genocide Convention did not, by becoming parties, grant jurisdiction to or in any other way alter their status or the status of their nationals relative to any international court that might in the future be created. See U.N. GAOR 6th Comm., 3d Sess., 130th mtg. at 684, 676 U.N. Doc. A/C.6/SR 61-140 (1948) (remarks of Mr. Fitzmaurice, U.K.) (stating that the U.K. "could not commit itself to support a court which did not yet exist and the scope of which was not known," and accepting Article VI only on the ground that it "put the court on a hypothetical, facultative basis and did not compel the parties to accept its jurisdiction"); LAWRENCE J. LEBLANC, THE United States AND the Genocide CONVENTION 165-67 (1991); Neremiah Robinson, The Genocide CONVENTION: A COMMENTARY 80 (1960); Matthew Lippman, The Convention on the Prevention and Punishment of the Crime of Genocide: Fifty Years Later, 15 ARIZ. J. INT'L \& COMP. L. 415, 461 (1998).

Neither does the Apartheid Convention constitute a precedent for the jurisdiction of an international tribunal over nationals of non-party states. The Apartheid Convention's provisions regarding an international penal tribunal echo those of the Genocide Convention, stating that persons charged with the crime of Apartheid may be tried in the national courts of states parties or "by an international penal tribunal having jurisdiction with respect to those states Parties having accepted its jurisdiction." International Convention on the Suppression and Punishment of the Crime of Apartheid, Nov. 30, 1973, art. V, 1015 U.N.T.S. 243 (emphasis added). Moreover, even with that safeguard, the jurisdictional provisions of the Apartheid Convention proved extremely controversial and were cited by many states 
The delegated universal jurisdiction theory of ICC jurisdiction over nonparty nationals, in sum, faces a number of difficulties. The delegated universal jurisdiction theory does not account for a number of crimes within the subjectmatter jurisdiction of the ICC that are not subject to universal jurisdiction. More importantly, because universal jurisdiction delegated to an international court would have materially different implications for states than would the exercise of universal jurisdiction by individual states, consent to the latter is not equivalent to consent to the former. For that reason, customary development of one should not be presumed to entail customary development of the other.

Rather, the question whether the delegation of universal jurisdiction is lawful requires a distinct analysis. In pursuing that analysis, we have found no precedent in state practice for the delegation of universal jurisdiction to an international court. This absence of precedent precludes the possibility that delegability has been affirmatively entailed within the customary law of universal jurisdiction as it has developed through state practice and opinio juris. It remains to be considered whether delegation of universal jurisdiction to an international court, even if not affirmatively entailed within the customary international law of universal jurisdiction, may nevertheless be lawful. That question will be examined shortly. First, however, we will consider an alternative theory supporting ICC jurisdiction over non-party nationals, based on the delegated territorial jurisdiction of states.

\section{B. Delegated Territorial Jurisdiction}

The jurisdictional provisions of the ICC Treaty suggest an alternative to the delegated universal jurisdiction theory of ICC jurisdiction over non-party nationals. This alternative approach would rest on a theory of delegated territorial jurisdiction. The notion here is that, when a non-party national is prosecuted before the ICC for crimes committed on the territory of a state that consents to ICC jurisdiction, the ICC exercises territorial jurisdiction that is delegated to the Court by the territorial state. Under Article 12 of the ICC Treaty, the ICC may exercise jurisdiction if the territorial state is a state party or provides ad hoc consent. If the territorial state, which would ordinarily have jurisdiction, may delegate that territorial jurisdiction to a court outside its own national judicial system, including an international court, then arguably the ICC may legitimately exercise that delegated jurisdiction.

Here, the question arises whether, as a matter of customary international law, territorial jurisdiction may be delegated to an international court without the consent of the defendant's state of nationality. As we shall see, the consequences of delegated territorial jurisdiction are quite different from those of territorial jurisdiction exercised by the territorial state, particularly for interstate-dispute type cases. As was true in the case of universal jurisdiction, be-

as among their reasons for rejecting the convention. See 27 YEARBOOK OF THE U.N. 100 (1973) (remarks of Finland [speaking also on behalf of Denmark, Iceland, Norway, and Sweden], Turkey, United States, Portugal, Spain, United Kingdom, Australia, Costa Rica, Equador, and France). 
cause the implications of state-exercised jurisdiction and jurisdiction exercised by an international court are not equivalent, states' consent to one is not equivalent to states' consent to the other. We may not simply assume, therefore, that states' territorial jurisdiction may be delegated to an international criminal court as a matter of customary law.

It will be useful to consider first whether a state's territorial jurisdiction may be delegated to another state and then to ask whether it may be delegated to an international court. It appears that a state may, under some circumstances, delegate its territorial jurisdiction over a given case to another state. ${ }^{115}$ Delegated or "vicarious" jurisdiction is unproblematic when the defendant's state of nationality consents. Such vicarious exercise of jurisdiction with consent by the state of nationality occurs, for example, among parties to the European Convention on the Transfer of Proceedings in Criminal Matters. ${ }^{116}$

It is less clear that a state may delegate its territorial jurisdiction to another state in the absence of consent by the defendant's state of nationality. There seems to be no precedent for such exercise of jurisdiction, including under the European Convention on Transfer of Proceedings in Criminal Matters. ${ }^{117}$ The possibility of transfer of jurisdiction where the defendant is a national of a thirdparty state is not precluded by the terms of that convention, which provide that "[f] or the purposes of applying this Convention, any Contracting state shall have competence to prosecute under its own criminal law any offence to which the law of another Contracting state is applicable."118 It appears that in practice, however, there has been no case of a transfer of criminal proceedings under the convention in which the defendant was a national of a non-party to the convention and the state of nationality did not consent to the transfer. ${ }^{119}$ If such a transfer of proceedings were attempted, involving a delegation of territorial jurisdiction without the consent of the defendant's state of nationality, that state of nationality might well protest the prosecution as an invalid exercise of jurisdiction. It would remain to be seen what the result would be of such a challenge. ${ }^{120}$

115. See Ethan A. Nadelman, The Role of the United States in the International Enforcement of Criminal Law, 31 HARV. INT'L L.J. 37, 69-70 (1990) (discussing vicarious jurisdiction).

116. See The European Convention on the Transfer of Proceedings in Criminal Matters, Mar. 30, 1978, Europ. T.S. No. 73.

117. See id.

118. See id. art. 2(1).

119. See Communication from M. Cunha, Responsable de l'application des conventions pénales du Conseil de l'Europe (conveyed via Marc Henzelin, University of Geneva Faculty of Law) (on file with author).

120. In 1988, a Select Committee of Experts on Extraterritorial Jurisdiction, convened by the Council of Europe's Committee on Crime Problems, rendered an analysis of the exercise of extraterritorial jurisdiction in Europe including jurisdiction exercised pursuant to the European Convention on Transfer of Proceedings in Criminal Matters. See Council of Europe, SElECT CoMmitTEE OF EXPERTS ON EXTRATERRITORIAL JURISDICTION, EXTRATERRITORIAL CRIMINAL JURISDICTION (1990). The Committee did not, in the course of its deliberations or in its published study, examine the question of the applicability of the convention to cases where defendants were non-party nationals. See Telephone Interview with Maurice Harari, Scientific Expert, Council of Europe's Select Committee of Experts on Extraterritorial Jurisdiction, in Geneva, Switz. (May 10, 1999). 
If it is dubious that territorial jurisdiction may be delegated from one state to another without consent by the state of nationality, it is even less clear that territorial jurisdiction may be delegated, without that consent, to an international court. There has been no previous instance of delegation of territorial jurisdiction to an international court. Of the four international courts in recent history, the ICTY/R and the Nuremberg and Tokyo tribunals, none has based its jurisdiction on delegated territorial jurisdiction. As discussed earlier, the ICTY/R base their jurisdiction on the Security Council's Chapter VII powers, and the Nuremberg and Tokyo tribunals each founded its jurisdiction on the consent of the state of nationality. ${ }^{121}$ (Indeed, far from basing jurisdiction on delegated territoriality, the Charter of the Nuremberg Tribunal specifically indicated that the Tribunal was to prosecute war criminals "whose offenses have no particular geographical location."122)

Beyond the absence of precedent in state practice, there are legally significant reasons that states might object to the delegation of a state's jurisdiction to an international court. These reasons, elaborated earlier in the context of universal jurisdiction, arise from the fact that the consequences for states of the compulsory jurisdiction of an international court are fundamentally different from the consequences of the jurisdiction of national courts. As was discussed at length above, the delegation of a state's jurisdiction to an international court may raise concerns for states regarding the diminished availability of compromise outcomes in interstate disputes, the heightened political impact of verdicts, the role of an international court in shaping the law, and the possible impediments to diplomatic protection of nationals. ${ }^{123}$ Transforming territorial jurisdiction into ICC jurisdiction through delegation would thus produce jurisdictional features entirely distinct from those envisioned in the customary law of territorial jurisdiction. For this reason, coupled with the absence of precedent for the delegation of territorial jurisdiction to an international court, it does not appear that the customary international law of territorial jurisdiction, as that law has evolved through state practice and opinio juris, has entailed the option of the delegation of territorial jurisdiction to an international court.

Not only does the delegation of territorial jurisdiction to an international court lack grounding in customary international law, but the delegation of states' territorial jurisdiction may also be subject to abuse. The primary basis for the unquestioned place of territorial jurisdiction among internationally recognized bases for jurisdiction is the fact that the state where the crime occurred is presumed to have a legitimate interest in seeing that the crime is punished. That crucial linkage between territorial jurisdiction and the legitimate prosecutorial interests of the territorial state would be broken if territorial jurisdiction

121. See supra text accompanying notes 90-113.

122. Agreement for the Prosecution and Punishment of the Major War Criminals of the European Axis and the Charter of the International Military Tribunal annexed thereto, Aug. 8, 1945, art.1, 82 U.N.T.S. 279.

123. See supra Part IIIA1. 
were delegated to a state on whose territory the crime did not occur. With that linkage broken, the door may be opened to the exercise of jurisdiction for illegitimate or abusive purposes.

To illustrate the problem, it may be helpful to consider an example involving a state-to-state delegation of jurisdiction. Imagine that France is holding for trial a U. S. national who has committed a crime on French territory. The United States has no basis to object to the exercise by France of its territorial jurisdiction over the U.S. national. Now let us imagine that France proposes to delegate its territorial jurisdiction to Libya and to transfer the defendant to Libya for prosecution. (Just to flesh out the tale, let us say that Libya is holding a French national for trial and is willing to transfer that case to France in exchange for the case of the U.S. national.) The United States would be correct in arguing that Libya does not have territorial (or any other internationally recognized basis for) jurisdiction and that France cannot confer, by delegation or otherwise, territorial jurisdiction upon a state on whose territory the conduct did not occur. While France has a recognized and legitimate interest in the punishment of the crime committed on French territory, Libya lacks that nexus with the crime that forms the basis for territorial jurisdiction. Libya might be motivated to make the jurisdictional trade for reasons that were illegitimate or abusive, for instance, to strengthen its hand in its political dealings with the United States. In any case, the traded jurisdiction would not conform with the principles (in particular, the recognition of the legitimate prosecutorial interests of the territorial state) on which territorial jurisdiction is founded.

The potential for abuse arising from delegation of territorial jurisdiction between individual states presumably is reduced where the jurisdiction is transferred not to an individual state but, rather, to an international court. Where that international court is controlled by a large number of states, the various states parties may provide checks and balances against abuses being perpetrated in the interests of one state or a small group of states. The ICC Treaty provides that the treaty will come into force only when there are a minimum of sixty states parties. Since most of those sixty or more states presumably would be disinclined to permit the Court to be used for the corrupt purposes of one or a few states, corrupt motives would be unlikely to prevail.

Nevertheless, while the potential for abuse may be thus reduced, it is not eliminated. At the beginning of the twenty-first century, the world is not divided into opposing camps, as it was during the decades of the cold war. In the current political context, sixty states would represent an assortment of crosscutting interests, which would make it difficult for one state or faction to turn the court to the service of its own purposes. But the re-emergence of a bipolar (or even tripolar) world, along any number of foreseeable or unforeseeable fault lines, is not difficult to imagine. In a polarized world, sixty states could represent one faction or at least be amenable to strong influence by one or a few states. In such circumstances, the potential for the abusive delegation of territorial jurisdiction would not be negated by the requirement that the ICC 
Treaty have at least sixty states parties to come into force. Rather, in those circumstances, permitting territorial jurisdiction to be treated as a form of negotiable instrument, to be used or conveyed, could have unintended and destructive consequences.

We have seen that there is an absence of precedent in state practice for the delegation of territorial jurisdiction to an international court. We also have seen that such delegation would have implications and consequences that are significantly different from those envisioned in the customary international law of territorial jurisdiction. These factors, in combination, suggest strongly that delegability to an international court is not entailed in the existing customary law of territorial jurisdiction.

C. The Lawfulness of Delegated Universal Jurisdiction or Delegated

Territorial Jurisdiction as a Legal Innovation

Even if the option of delegating universal or territorial jurisdiction to an international court is not affirmatively encompassed within the existing customary law of universal or territorial jurisdiction, such a delegation of jurisdiction might nevertheless be lawful. The present section will consider this possibility.

In the Lotus Case, ${ }^{124}$ the Permanent Court of International Justice ("PCIJ") stated in dictum that, where a prosecuting state's jurisdiction is challenged, the burden rests with the challenging state to show what rule of international law the exercise of jurisdiction violates, and does not rest with the prosecuting state to show what principle of international law supports the jurisdiction. If Lotus were to be read in its strongest possible sense, then virtually all innovative bases for jurisdiction, including delegation of states' universal or territorial jurisdiction to the ICC, would be permissible since, being new, there would be, as yet, no rule against them. ${ }^{125}$

But that strong reading of Lotus, even if it were good law when Lotus was decided (which is itself doubtful ${ }^{126}$ ), is not an accurate description of the law now. ${ }^{127}$ Rather than being strictly based on an open-endedly permissive view that all jurisdiction is lawful unless the challenging state can point to a rule that it violates, the customary international law of criminal jurisdiction is based on a perceptible, if somewhat ill-defined, set of principles regarding the legitimate prosecutorial interests of states. In most criminal cases, those underlying prin-

124. S.S. Lotus (Fr. v. Turk.), 1927 P.C.I.J. (ser. A) No. 9 (Sept. 7).

125. For an application of this approach to ICC jurisdiction over non-party nationals, see Scharf, supra note 68 , at $72-73$.

126. The Lotus decision was controversial. The decision was rendered by an evenly divided court, with the president of the court breaking the tie with a casting vote. At the time of Lotus's publication, the academic literature was replete with vociferous objections to the court's reasoning. See IAN BROWNLIE, PRINCIPLES OF PUBLIC INTERNATIONAL LAW 302 n. 24 (4th ed. 1990) (and sources cited therein); Fritz A. MANN, StUdies IN INTERNATIONAL LAW 26 n.3 (1973) (and sources cited therein).

127. See BRownLIE, supra note 126, at 302-03; MANN, supra note 126, at 26-27; Prosper Weil, International Law Limitations on State Jurisdiction, in EXTRATERRITORIAL APPLICATION OF LAWS AND RESPONSES THERETO (Cecil Olmstead ed., 1983). 
ciples are not relied upon explicitly, because the customary law of criminal jurisdiction recognizes an identifiable set of valid bases for jurisdiction. When jurisdiction can be justified by reference to one of those recognized bases, as is usually the case, reiteration of the underlying principles concerning the legitimate prosecutorial interests of states is not necessary.

The usual list of internationally recognized bases of jurisdiction includes: territoriality, nationality, protective principle, universality, and passive personality (the last being the least robustly accepted). Some influential authorities maintain that this list is exclusive. ${ }^{128}$ Because the list of recognized bases for jurisdiction is not arbitrary but has developed to reflect an evolving delineation of the legitimate prosecutorial interests of states, it is unlikely that the list is actually closed. Rather, what appears to be true is that jurisdictional bases that are already recognized are uncontroversially acceptable, while the legitimacy of claimed new bases must be determined.

Michael Akehurst has noted that

[w] hat is significant is the fact that writers almost always list specific heads of jurisdiction, thereby implying that all other types of jurisdiction are illegal, instead of simply stating the general presumption that all types of jurisdiction are legal and then listing specific heads of jurisdiction which are proved to be illegal. ${ }^{129}$

Akehurst is correct in observing that the practice of enumerating specific heads of jurisdiction that are lawful, rather than listing heads of jurisdiction that are prohibited, is both pervasive and significant. Any number of articles and briefs, after briefly citing Lotus, proceed to devote lengthy arguments to demonstrating that the jurisdiction being argued for fits into one or more of the five recognized bases for jurisdiction. Lotus itself is a specimen of this sort. After articulating the broad "Lotus principle" that "restrictions on the independence of states cannot ... be presumed", ${ }^{130}$ the court then proceeded to base its decision, upholding a challenged exercise of jurisdiction, largely on an argument that the jurisdiction asserted was a form of territorial jurisdiction. The court interpreted territorial jurisdiction to encompass the territorial effects theory-which the court was then at pains to demonstrate had been previously internationally accepted as a valid basis for jurisdiction! $!^{131}$

Were the lesson of Lotus very simply that jurisdiction is legitimate unless it violates an identifiable rule, then it would be hard to explain why the Lotus court went to great effort to show that the jurisdiction that it was upholding fell within a previously approved category of jurisdiction. Whatever the Lotus court's dicta, its opinion in toto reflects the subtler reality that determining the

128. See, e.g., OSCAR SCHACHTER, INTERNATIONAL LAW IN THEORY AND PRACTICE 254-55, 257 (1991) ("[a]ny one of the [list of five] bases of jurisdiction just mentioned may meet the minimum international law requirements for jurisdiction to prescribe. If none is present, the application of domestic law in the particular case would be 'exorbitant' that is, impermissible."); RESEARCH IN INTERNATIONAL LAW OF THE HARVARD LAW SCHOOL, II JURISDICTION WITH RESPECT TO CRIME, DRAFT CONVENTION WITH COMMENT, Supplement to 29 AM. J. INT'L L. 435, 445, 446 (1935).

129. Michael Akehurst, Jurisdiction in International Law, 46 BRIT. Y.B. INT'L L. 145, 167 (1972-73).

130. S.S. Lotus (Fr. v. Turk.), 1927 P.C.I.J. (Ser. A) No. 9, at 18.

131. See id. 
acceptability of a claimed form of jurisdiction requires either the short-cut of demonstrating that the jurisdiction falls within a previously accepted category, or the more complex task of determining whether the form of jurisdiction claimed comports with the underlying principles governing the international law of jurisdiction.

In addition to the writings of courts and commentators, state practice too reflects the fact that there is an identifiable universe of recognized bases for jurisdiction under international law and an identifiable (even if not fully defined) set of principles underlying those bases. When one state challenges another's exercise of jurisdiction, the challenged state routinely responds by reference to one or more of the internationally recognized bases for jurisdiction and, where warranted, to the rationales underlying those bases. ${ }^{132}$ This approach stands to reason. It cannot be that any new basis for jurisdiction, however extravagant or nonsensical, is legitimate simply because it has not been previously claimed and has, therefore, not been previously rejected.

The point here is not to question the very general precept of Lotus that international law leaves to states "a wide measure of discretion which is only limited in certain cases by prohibitive rules." ${ }^{, 133}$ Rather, the point is that the general precept articulated in Lotus must be read together with the other principles underlying and defining the customary law of jurisdiction. In short, the legitimacy of claimed new forms of jurisdiction must be determined, not assumed. The Lotus case places the burden of proof for this determination on the challenging state, but Lotus does not eliminate the necessity of making the determination of whether a claimed new form of jurisdiction is legitimate.

When a new basis for jurisdiction is claimed or proposed, its validity is evaluated by consideration of its appropriateness, measured in terms of the underlying principles and rationales governing jurisdiction under customary international law. Typically, this evaluation of appropriateness has meant a form of nexus analysis. The central question has been whether the conduct to be regulated is sufficiently linked to the legitimate interests of the state claiming jurisdiction to warrant recognition of jurisdiction. As Professor Mann puts it, "in essence criminal jurisdiction is determined not by such external, mechanical and inflexible tests as territoriality or nationality, but by the closeness of a state's connection with, or the intimacy and legitimacy of its interests in, the facts in issue." $" 134$

But this sort of nexus analysis would be inapposite in determining the appropriateness of ICC jurisdiction over non-party nationals. The ICC is not a state and has no "interests" of its own apart from those delegated to it by the states parties to the Treaty. This is where nexus analysis fails us: The legitimacy

132. See generally VAUGHN LOWE, EXTRATERRITORIAL JURISDICTION: AN ANNOTATED COLLECTION OF LEGAL MATERIALS (1983) (reviewing a multitude of challenges by one state of another's asserted jurisdiction); $c f$. Attorney General of Israel v. Eichmann , 36 I.L.R. 283-87 (1962) (citing Lotus to support jurisdiction but then relying extensively on other, positive bases).

133. See Lotus, 1927 P.C.I.J. at 18.

134. See MANN, supra note 126 , at 80. 
of the original jurisdiction (universal or territorial) of those states parties, based on their legitimate state interests, is not questioned here. What is at issue, rather, is the validity of the delegation of that jurisdiction, an issue with respect to which nexus analysis is unhelpful.

In evaluating the appropriateness of the delegation of universal or territorial jurisdiction, it may be useful to begin by articulating the basic principle, perhaps rising to the level of a general principle of law, that legal relations that are based on mutual consent (or acquiescence) may not be altered by one party to the detriment of the other. In treaty law and contract law, this principle is reflected in the axiom "pacta sunt servanda." 135 In the context of customary international law, the principle prohibiting unilateral alteration of legal relations that are based on consent or acquiescence is reflected in the requirement that customary law develop through pervasive state practice and opinio juris.

Universal and territorial jurisdiction exist within and are defined by customary international law. Customary international law, in turn, comes into being through the consent or acquiescence of states over time. In this way, the definition and parameters of universal and territorial jurisdiction have come into being through the consent and acquiescence of states. The rights and obligations of states relative to universal and territorial jurisdiction thus constitute a set of legal relations based on mutual consent and acquiescence over time.

In the debate about ICC jurisdiction over non-party nationals, there is no controversy about the principle that legal relations based on mutual consent or acquiescence may not unilaterally be materially altered. ${ }^{136}$ Nor is there any controversy over the proposition that the law of universal and territorial jurisdiction is customary law which, in turn, is founded on the consent or acquiescence of states. Rather, the debate concerns whether incorporating the option of delegating universal or territorial jurisdiction to an international court should be considered to constitute a material alteration of the law of universal and territorial jurisdiction.

In addressing this question, we may benefit from an examination of the treatment of an analogous question in another area of law. The law of assignments addresses the question of whether and when the delegation or, more properly, the "assignment" of a right ${ }^{137}$ should be considered a material alteration to a legal relationship. The law of assignments outlines an approach to this question that is suggestive for the present problem regarding the delegation of jurisdiction.

In the assignments context, the question is whether a party holding a contractual right may assign that right to a third party. The basic principle of the

135. Translated as "Agreements (and stipulations) of the parties (to a contract) must be observed." BLACK's LAW DICTIONARY 998 (5th ed. 1979).

136. $C f$. infra Part IVB (regarding whether the ICC Treaty has already altered customary law).

137. In the context of the ICC debate, the word "delegation" has been used to refer to the transfer of a right (to prosecute). This language is different from that used in the law of assignments, in which "assignment" would refer to the transfer of a right while "delegation" would refer to transfer of an obligation. 
law of assignments, which is pervasively applied in municipal law ${ }^{138}$ and private international law, ${ }^{139}$ is that rights may be assigned only when the assignment does not prejudice the obligor's position. ${ }^{140}$ As described in the Restatement of Contracts 2d, "[a] contractual right may be assigned unless [] the substitution of a right of the assignee for the right of the assignor would materially change the duty of the obligor, or materially increase the burden or risk imposed on him ...."141 While assignment is not generally a feature of public international law, ${ }^{142}$ proposals to incorporate the concept of assignment into the law of treaties consistently treat as foundational the principle of non-prejudice to the interests of the obligor. ${ }^{143}$ The non-prejudice rule provides a method for upholding, in cases in which assignment of a right is contemplated, the principle that legal relations that are based on mutual consent or acquiescence may not be materially altered by one party to the detriment of the other.

As was argued earlier, the delegation of states' universal or territorial jurisdiction to an international court would materially increase the risk or burden imposed on a state whose national may be subject to prosecution for an international crime. This increased risk or burden arises, primarily in interstatedispute type cases, ${ }^{144}$ from the elimination of states' discretion regarding methods of interstate dispute resolution, and from the potential practical, political, and precedential disadvantages that this loss of discretion implies. Applying the non-prejudice principle to the question whether states may delegate (or "assign") jurisdiction to the ICC would lead to the conclusion that the delegation of jurisdiction from a state to the ICC is not permissible without the consent of what might be called the obligor state (the defendant's state of nationality) because it would materially increase the burden or risk imposed on that state.

The point here is not to suggest that the law of assignments has legal force in the very different field of the customary international law of jurisdiction. The relevance of the law of assignments is that it is a body of law concerned centrally with the question of when the delegation of a right is permissible, and that it offers a cogent framework for approaching that issue. The law of assignments is therefore suggestive of how we might usefully evaluate whether and when the delegation of jurisdiction should be considered permissible. That evaluation indicates that the delegation of states' universal or territorial jurisdiction to the ICC would be impermissible because it would materially alter the legal relation-

138. See MANN, supra note 126 , at 363.

139. See, e.g., U.N. COMM'N ON INT'L Trade L., Draft CONVENTION ON AssignMENT OF RECEIVABLES FINANCING: TEXT WITH REMARKS AND SUGGESTIONS, U.N. Doc. A/CN.9/WG.II/WP.104 (July 16, 1999).

140. See MANN, supra note 126, at 363.

141. See Restatement (SECOND) OF CONTRACTS § 317(2) (1981).

142. See BROWNLIE, supra note 126 , at 678.

143. See, e.g., Christine ChINKIN, ThIRD PARTIES IN INTERNATIONAL LAW 58 (1992); MANN, supra note 126, at 363 ("the paramount rule being that [the obligor's] position is not to be prejudiced as a result of the assignment").

144. There may also be increased burdens and risks in individual-culpability cases if a state wishes to provide diplomatic protection. See supra note 81. 
ships constituting the customary law of jurisdiction, and would do so to the detriment of non-party states without their consent.

The previous section of this article concluded that delegability to an international court is not a feature of universal or territorial jurisdiction under existing customary international law. The present section, which has analyzed the appropriateness of delegated universal or territorial jurisdiction as an innovative form of jurisdiction, suggests that delegation of universal or territorial jurisdiction to an international court would not constitute an appropriate innovation. Consequently, it appears that conceptualizing ICC jurisdiction over non-party nationals as the delegated jurisdiction of states does not provide an adequate legal foundation for the jurisdiction claimed. The next and final part of this article will consider whether there may be some other legal foundation for ICC jurisdiction over non-party nationals that does not rest on a theory of delegated jurisdiction.

\section{IV}

\section{JURISDICTION WITHOUT DELEGATION}

Eliminating the delegated jurisdiction theories, as appears to be warranted, leads us to consider whether there is a legal basis for the ICC Treaty's creating ICC jurisdiction over non-party nationals as a strictly new base of jurisdiction. Such a legal basis might rest upon a theory of global treaties, or a theory of the ICC Treaty as generating new customary law, or on an analogy between the ICC Treaty and the anti-terrorism treaties.

\section{A. Global Treaties}

It has been suggested that there exists a genre of treaties that are globally binding because they foster the common interests of humanity. ${ }^{145}$ The ICC Treaty might be thought to fall within that genre. If the ICC Treaty were globally binding, then all states would be bound to accept the treaty's jurisdictional provisions even if those provisions departed from the customary international law of jurisdiction.

A threshold problem with the theory of global treaties is that there will inevitably be disagreement about what in fact will serve the common interests of humanity. An equally formidable problem confronting the theory of global treaties is that, even if that which would serve the common interests of humanity could be dispositively identified, that alone would not bind states who would find unacceptable a particular distribution of the burdens involved in serving those interests. For both of these reasons, the mere invocation of common interests does not resolve the matter.

An effort was made by some states to treat the U.N. Convention on the Law of the Sea as globally binding by virtue of its perceived importance for the

145. See GenNADy M. DANILENKO, LAw-MAKING In THE INTERNATIONAL COMmunity 64-68 (1993). 
common interests of humanity. ${ }^{146}$ Just as one might expect, notwithstanding declarations by some states that the deep sea-bed mining regime of the Law of the Sea Convention was binding on non parties, non-party states rejected that view and proceeded with legislation and agreements regarding reciprocal recognition of mining sites that were prohibited by the treaty. ${ }^{147}$ The point here is not that states flout treaties. Rather, the point is that invocation of the interests of humanity does not resolve political debate, and it has not proved successful in binding non-parties to treaty obligations.

In the ICC context, the United States has argued, in effect, that humanity is best served by the U.S. remaining free in its peacekeeping and humanitarian activities from such inhibitions as implementation of the current ICC Treaty would pose..$^{148}$ As Ambassador Scheffer has stated,

[t]he illogical consequence imposed by Article 12, particularly for non-parties to the treaty, will be to limit severely those lawful, but highly controversial and inherently risky, interventions that the advocates of human rights and world peace so desperately seek from the United States and other military powers. There will be significant new legal and political risks in such interventions ....

Proponents of the ICC Treaty take the view that the benefits to humanity offered by implementation of the treaty would outweigh whatever might be lost by way of inhibition of U.S. humanitarian action. Regardless of the merits of that debate, invocation of the interests of humanity clearly does not resolve the issue and only raises again the question of who has the right to decide. Claiming that a particular treaty serves the common interests of humanity does nothing fundamentally to alter the debate.

Before leaving this debate, however, we must examine what some might view as the best example of a treaty entailing global application by virtue of its claim to global benefits. This is the United Nations Charter and, particularly, Article 2 of the charter, which enunciates the charter's fundamental principles. Article 2(6) of the charter states: "The organization shall ensure that states which are not members of the United Nations act in accordance with these principles so far as that may be necessary for the maintenance of international peace and security." Some authorities interpret that article as reflecting that the charter imposes obligations on non-members of the United Nations. ${ }^{150}$ But that view is controversial. ${ }^{151}$ An alternative interpretation is that

Article 2(6) is addressed to the United Nations and its members. While members of the organization may be under a charter obligation to ensure that all states act in ac-

146. See id. at 66.

147. See id.

148. See supra text accompanying note 204.

149. David J. Scheffer, The United States and the International Criminal Court, 93 AM. J. INT'L L. 12, 19 (1999).

150. See, e.g., Brownlie, supra note 126, at 694; Richard FALK, THE STATUS OF LAW IN INTERNATIONAL SOCIETY 185 (1970).

151. See generally BRUno Simma ET AL., THE Charter of THE United NATIOnS: A COMMENTARY 131-39 (1994) (discussing Article 2(6) of the U.N. Charter and the controversy regarding the legal effects of the charter on non-members of the U.N.). 
cordance with the Charter, as a treaty provision this rule still remains inter alios acta for the third states which are under no legal duty to comply with it. Indeed, the practice of non-member states shows that they do not consider themselves as legally bound by the Charter of the United Nations. ${ }^{15}$

Certainly, non-members of the United Nations, including Switzerland, take the view that they are not bound by the charter. ${ }^{153}$

Whatever may be the current status of U.N. Charter Article 2(6) with regard to binding third parties, the only relevant issue in drawing an analogy with the current status of the ICC Treaty is the status of third parties relative to the charter at the time of its adoption. Even if we were to assume that customary law has developed in the years since the charter's adoption, such that the principles referred to in Article 2(6) are now binding on non-parties, this would imply nothing for the ICC Treaty except that, in future years, customary law might develop such that aspects of the ICC Treaty would pass into customary law and thereby become binding on non-parties to the Treaty. ${ }^{154}$ What is relevant for present purposes is not whether the U.N. Charter has come to bind non-parties as a matter of subsequent custom but whether it bound nonparties upon its adoption by virtue of its humanitarian aims and global purposes. ${ }^{155}$

The present analysis of whether Article 2(6) was regarded as binding on non-parties at the time of the U.N. Charter's adoption will be limited to analysis of the U.N. Charter as a multilateral treaty. There are those who argue that Article 2(6) has bound non-members since the charter's adoption by virtue of the charter's being a "world constitution" $" 156$ or other unique instrument. ${ }^{157}$ Whatever the merits of those claims, they are, by their very nature, inapplicable to the ICC Treaty. Viewing the charter as a treaty (and therefore analogous in at least some ways to the ICC Treaty), we must conclude that the charter did not, upon adoption, bind third parties to obligations not previously existing under customary law.

Bentwich and Martin's 1950 Commentary on the Charter of the United Nations states:

[T]he Charter does not purport to impose legal obligations on non-members. It does, however, impose upon the Organization itself an obligation to ensure-by persuasion, if possible, but by the application of force, if necessary-the compliance of non-

152. DANILENKO, supra note 145, at 60; see also RICHARD A. FALK, The Authority of the United Nations to Control Non-Members 73-74 (1965). But see Kunz, Revolutionary Creation of Norms of International Law, 41 AM. J. INT'L L. 119,124 (1947) (taking the view that this analysis evades the core issue of the legal authority of the United Nations to exercise power over non-members); OPPENHEIMLAUTERPACHT, INTERNATIONAL LAW 928 (8th ed. 1955) (same).

153. See 26 SJIR 84-88 (1970) (official statement of Swiss position); 39 SJIR 264-67 (1983) (same).

154. As to the question whether customary law developments prompted by the charter itself have given rise to a new customary regime of global treaties, see infra text accompanying notes 169-180.

155. The prospect of the ICC Treaty passing into customary law will be considered infra Part IVB.

156. FALK, supra note 152, at 51; see, e.g., Ross, CONSTITUTION OF THE UNITED NATIONS 32 (1950); Bardo Fassbender, The United Nations Charter as Constitution of the International Community, 36 COLUM. J. TRANSNAT'L L. 529 (1998).

157. See FALK, supra note 152, at 66-67, 70, 101. 
members with the Principles of the United Nations. The former will have to obey not as a matter of law, but as the result of the realities of power. ${ }^{158}$

Numerous such commentaries, reflecting the view that the U.N. Charter did not legally bind non-parties, were written in the early years of the United Nations' existence. Those early commentators on the U.N. Charter who viewed the charter as a treaty virtually uniformly took this position. ${ }^{159}$

There is also reflected in the writing of that time, however, an increasing anticipation that the advent of the U.N. system itself and its charter provisions might lead to an erosion in some contexts of the principle that treaties cannot bind third parties. The treatment of this issue in successive editions of the Oppenheim-Lauterpacht treatise on international law is illustrative. Lauterpacht wrote in the seventh edition in 1948 that "[n]on-members are not bound by [Article 2(6)] and they may choose to react accordingly."160 By the eighth edition, published in 1955, Lauterpacht wrote,

International Law does not as yet recognize anything in the nature of a legislative process by which rules of law are imposed upon a dissenting minority of states. However, in proportion as international society is transformed into an integrated community, a departure from the accepted principle becomes unavoidable, in particular in the sphere of preservation of international peace and security.... Both the Covenant... and the Charter ... must therefore be regarded as having set a limit, determined by the general interest of the international community, to the rule that a treaty cannot impose obligations upon states which are not parties to it. ${ }^{161}$

There is a similar progression in the treatment of Article 2(6) in successive editions of Goodrich and Hambro's commentaries on the U.N. Charter. The first edition, published in 1946 states that

[t]he Charter does not of course create any legal obligation for states not Members of the Organization. They are therefore not obligated in a legal sense to act according to the Principles of the Charter for any purpose whatsoever. The Charter system therefore provides for the imposition, by force if necessary, of the prescribed conduct without any legal basis in contractual agreement. ${ }^{162}$

By 1949, Goodrich and Hambro had softened their language, stating, "[i]t is doubtful whether an international instrument can impose legal obligations on states which are not parties to it. The traditional theory, which is not unanimously held [here, the authors cite Kelsen], is that treaties cannot obligate third parties." ${ }^{163}$

158. NORMAN BENTWICH \& ANDREW MARTin, A COMMENTARY ON THE CHARTER OF THE UNITED NATIONS 14 (1950).

159. See, e.g., id. at 14; Leland M. Goodrich \& Edvard I. Hambro, THE Charter of the UNITED NATIONS: COMMENTARY AND DOCUMENTS 108-10 (1st ed. 1946); 1 GUGGENHEIM, LEHRBUCH DES VOLKERRECHTS 92 (1948); I OPPENHEIM-LAUTERPACHT, INTERNATIONAL LAW 928-29 (7th ed. 1948); Kunz, General International Law and the Law of International Organizations, 48 AM. J. INT'L L. 456, 457 (1953); Kunz, supra note 152, at 119-26; cf. PHILIP C. JESSUP, A MODERN LAW OF NATIONS 168 (1948).

160. 1 OPPENHEIM-LAUTERPACHT, INTERNATIONAL LAW 652 (8th ed. 1955).

161. Id.

162. LelAnd M. GOODRICH \& EdVARD I. HAMBro, THE CHARTER OF THE UNITED NATIONS: COMMENTARY AND DOCUMENTS 71 (1st ed. 1946).

163. Id. at $108-09$ ( 2 d ed. 1949). 
Hans Kelsen has indeed been prominently, but somewhat erroneously, associated with the view that Article 2(6) bound non-members to new obligations from the time of the charter's adoption. He stated in his 1950 book that

non-Member states are obliged by the Charter, just as Members are, to settle their disputes by peaceful means, to refrain in the relation to other States from the threat or use of force, to give the United Nations every assistance in any action it takes in accordance with the Charter, and to refrain from giving assistance to any state against which the United Nations is taking preventive or enforcement action. ${ }^{164}$

But Kelsen seems to have meant not that this interpretation of Article 2(6) was law in 1950 but, rather, that such an interpretation of Article 2(6) could or should be law, the final ascertainment of which, however, would have to await the development of custom. As Kelsen wrote, continuing the passage quoted above:

From the point of view of existing international law, the attempt of the Charter to apply to states which are not contracting parties to it must be characterized as revolutionary. Whether it will be considered as a violation of the old, or as the beginning of a new international law, remains to be seen. ${ }^{165}$

Thus, the prevailing view at the time of the U.N. Charter's adoption was that it was not binding on non-parties. There was some thought in the years following its adoption that the emergence of the U.N. system and the very fact of the charter's adoption, including Article 2(6), might effect a movement away from the strict application of the pacta tertiis principle. In retrospect, we may fairly conclude that such an expectation was not fulfilled. Rather, the scope of coverage of Article 2(6) remains somewhat controversial, ${ }^{166}$ and the authorities that do view the charter provisions as binding on non-parties generally maintain that this is so as a consequence of the development of customary law concerning the charter, not by virtue of an exception to the pacta tertiis principle. ${ }^{167}$ Significantly, the U.N. Charter has not proven to be the herald of a new era of international law featuring global treaties that bind parties and non-parties alike.

The U.N. Charter thus does not provide a precedential foundation for the ICC Treaty's binding non-parties. It would be bootstrapping to suggest that a theory of global treaties can be supported by a reference to the U.N. Charter, which itself was not regarded as "global" when adopted and which, even now, can claim universal applicability, if at all, only by virtue of the usual processes of customary law development.

In the end, the global treaty theory as a basis for ICC jurisdiction over nonparties is untenable not only as a matter of customary law but also as a practical matter. The practical problem is that the theory of global treaties merely reframes the question whether a treaty may bind non-parties as the question

164. Hans Kelsen, The LAW OF the United Nations: A CRitical ANAlysis of its FUNDAMENTAL PROBLEMS 107 (1950).

165. Id. at 110; see also Verdross, Le Nazioni Unite $e$ i Terzi state, 2 LA COMUNITA INTERNAZIONALE 455 (1947) (taking a similar view).

166. See SIMMA ET AL., supra note 151, at 131-39.

167. See id. at 137-38. 
whether a treaty may bind non-parties if it purports to pronounce what is best for humanity-without providing any means for resolving the inevitable disagreements about what is best for humanity and about distributing the burdens of achieving humanitarian goals.

The existence of jus cogens norms and erga omnes obligations does not help to resolve these issues. Jus cogens norms and erga omnes obligations include obligations on states to prevent and perhaps, in some circumstances, to prosecute and punish genocide, war crimes, and crimes against humanity-the crimes that form the subject-matter jurisdiction of the ICC. ${ }^{168}$ But those jus cogens norms and erga omnes obligations do not include a requirement that prevention and punishment occur through the mechanism of an international criminal court. Even while customary jus cogens and erga omnes norms have evolved in certain areas of substantive law, customary law has not developed, as we have seen, to require enforcement of that substantive law through an international court. In fact, as has been discussed, there are reasons for which alternatives to international adjudication may sometimes be preferable in cases that involve interstate legal disputes. Reference to the universally binding nature of the substantive norms of international criminal law cannot be relied on to do double duty to form the basis also for an argument that use of the ICC mechanism is also obligatory or that the ICC Treaty is a global treaty, with jurisdictional obligations binding on all states.

\section{B. The ICC Treaty as Generating Customary Law}

Even if a treaty cannot be said to bind non-parties simply by virtue of its claim to serving humanity, there remains the possibility that the content of a treaty may become part of customary law and thereby bind non-parties. Viewing the ICC solely in its posture as an adjudicator of individual culpability, one might conclude that ICC jurisdiction over non-party nationals would constitute only an incremental step in the development of customary law from the existing customary law of universal or territorial jurisdiction. When the ICC's role as an adjudicator of interstate disputes is also taken into account, however, the difference between states' universal or territorial jurisdiction and ICC jurisdiction is revealed to be very significant, as we have seen. When this second aspect of the ICC's character is considered, it becomes clear that establishing customary law supporting ICC jurisdiction over non-party nationals would involve not a minor or an incremental step but a distinct new departure in the law of jurisdiction.

Considering the process by which the content of a treaty may become part of customary law, the International Court of Justice ("ICJ") in the Continental Shelf case stated that,

168. See generally ANDRÉ DE HOOGH, OBLIGATIONS ERGA OMNES AND INTERNATIONAL CRIMES (1996) (on development of the erga omnes and jus cogens doctrines as applicable to international crime); cf. Prosper Weil, Towards Relative Normativity in International Law, 77 AM. J. INT'L L. 413 (1983) (questioning the wisdom of development of the jus cogens and erga omnes doctrines). 
[w]ith respect to the other elements usually regarded as necessary before a conventional rule can be considered to have become a general rule of international law, it might be that, even without the passage of any considerable period of time, a very widespread and representative participation in the convention might suffice of itself, provided it included that of states whose interests were specially affected....

Although the passage of only a short period of time is not necessarily, or of itself, a bar to the formation of a new rule of customary international law on the basis of what was originally a purely conventional rule, an indispensable requirement would be that within the period in question, short though it might be, state practice, including that of states whose interests are specially affected, should have been both extensive and virtually uniform in the sense of the provision invoked;-and should moreover have occurred in such a way as to show a general recognition that a rule of law or legal obligation is involved. ${ }^{169}$

It would be difficult to argue that the ICC Treaty has generated customary law supporting ICC jurisdiction over non-party nationals. There has been no period of time in which "extensive and virtually uniform" state practice has supported the form of jurisdiction in question. This is true even if we take the adoption of the ICC Treaty by 120 states at the Rome conference as a form of state practice. ${ }^{170}$ Even in a situation in which a treaty faced less opposition than did the ICC Treaty (seven states voted against adoption, twenty-one states abstained) ${ }^{171}$ reliance on adoption of a treaty at a diplomatic conference alone would be a precarious basis for a claim of creation of customary law. In the case of the ICC Treaty, with only twenty-seven states parties and 139 signatories at present, ${ }^{172}$ the ICC Treaty cannot be said to enjoy participation that is "very widespread and representative" much less "virtually uniform." As the ICJ stated in the Continental Shelf case, "the number of ratifications and accessions so far secured is ... hardly sufficient. That non-ratification may sometimes be due to factors other than active disapproval of the convention concerned can hardly constitute a basis on which positive acceptance of its principles can be implied." ${ }^{173}$

Nor does such participation as there is in the ICC Treaty actually include "that of states whose interests are specially affected." The United States, which is disproportionately involved in military activities throughout the world, has vocally rejected aspects of the treaty, most particularly including its jurisdictional provisions.

169. North Sea Continental Shelf (Den. v. F.R.G.), 1969 I.C.J. 3, at $42-43$ (Feb. 20).

170. On the debate regarding the treatment of treaty participation as a form of state practice for purposes of customary law development, see ANTHONY A. D'AMATO, THE CONCEPT OF CUSTOM IN INTERNATIONAL LAW 3-4, 89-90, 103-65 (1971); Oscar Schachter, Entangled Treaty and Custom, in INTERNATIONAL LAW AT A TIME OF PERPLEXITY 717, 724-26 (Yoram Dinstein ed., 1989); Arthur Weisburd, Customary International Law: The Problem of Treaties, 21 VAND. J. TRANSNAT'L L. 1 (1988).

171. United Nations Conference of Plenipotentiaries on the Establishment of an International Criminal Court, U.N. Diplomatic Conference Concludes in Rome with Decision to Establish Permanent International Court, Press Release L/ROM/22, July 17, 1998 (visited Mar. 22, 2000) <http://www.un.org/ icc/>.

172. United Nations, Rome Statute of International Criminal Court: Ratification Status (last modified Dec. 31, 2000) <http://www.un.org/law/icc/statute/status/htm>.

173. Continental Shelf, 169 I.C.J. at 42. 
Perhaps the most illuminating point regarding whether participation in the ICC Treaty can currently be said to constitute state practice sufficient to have generated customary law is simply that the treaty, by its own terms, requires sixty ratifications or accessions before it can come into force. The treaty's drafters recognized that this was the minimum degree of support that would be required before the ICC could become a credible international court. Because the treaty does not yet have the degree of adherence that the court's supporters recognized was required to make the court a credible international institution, and because the jurisdictional issue was among the most controversial aspects in the treaty negotiations, ${ }^{174}$ it is difficult to see how the treaty can be said already to have sufficient adherence, particularly on the issue of jurisdiction, to constitute the necessary state practice to generate customary law on ICC jurisdiction.

A number of scholars of customary international law have argued that state practice is not a separate element required for the generation of customary law but is relevant only as evidence of opinio juris. ${ }^{175}$ Based on that view, some have argued for the possibility of instant custom. ${ }^{176}$ All, however, ultimately rest their arguments for instant custom on the existence of consensus or virtual consensus regarding the subject at issue-a consensus which is obviously lacking in the case of the ICC Treaty.

Bin Cheng's theory of "instant customary law" begins with the premise that the fundamental substance of customary international law is opinio juris. Practice, he reasons, is not a constitutive element of custom but, rather, provides evidence of the existence and content of the requisite opinio juris. As he puts it,

[i]f States consider themselves bound by a given rule as a rule of international law, it is difficult to see why it should not be treated as such in so far as these states are concerned, especially when the rule does not infringe the right of third states not sharing the same opinio juris. ...

From this point of view, there is no reason why an opinio juris communis may not grow up in a very short period of time among all or simply some Members of the United Nations with the result that a new rule of international customary law comes into being among them....

There is no reason why a new opinio juris may not grow overnight between States so that a new rule of international customary law (or unwritten international law) comes into existence instantly. ${ }^{177}$

In Cheng's theory of "instant custom," then, we find simply the proposition that those who agree to be bound now may be bound now but may not bind others. ${ }^{178}$

174. See Philippe Kirsch \& John T. Holmes, The Rome Conference on an International Criminal Court: the Negotiating Process, 93 AM. J. INT'L L. 2, 7-9 (1999).

175. See, e.g., Bin Cheng, United Nations Resolutions on Outer Space: "Instant” International Customary Law?, 5 INDIAN J. OF INT’L L. 23 (1965).

176. See, e.g., id.

177. Cheng, supra note 175 , at $37,46$.

178. Even this proposition, which seems unexceptionable on its face, may in fact be problematic. By eliminating the requirement of consistent state practice over some period of time before binding customary law is created, Cheng would seem to suggest that states should be irrevocably bound without a period of time in which to observe and consider the incipient rule in practice. 
Anthony D'Amato has made a similar point, though he places greater emphasis on the need for consensus if all, rather than only some, states are to be bound:

To the extent that a widely adopted multilateral convention represents the consensus of states on the precepts contained therein those precepts are part of international law by that fact alone. In this sense, multilateral treaties are and historically have been more important than bilateral ones. But this effect is not due to anything connected with the concept of custom; it involves a separate phenomenon-"consensus"-which deserves separate study as to its nature, identification and provability. ${ }^{179}$

The theory of instant customary law and D'Amato's closely related theory of consensus can be eliminated as plausible bases for ICC jurisdiction over nonparty nationals. Those theories rest, as they must, on the observation that if consent is so pervasive as to be consensus then, all agreeing to be bound, all are bound. Such a consensus, or even pervasive acquiescence including specially interested states, is conspicuously absent in the case of the ICC Treaty. The treaty thus cannot currently be said to have created custom, instant or otherwise, with regard to ICC jurisdiction over non-party nationals. ${ }^{180}$

\section{The Terrorism Treaties}

A number of treaties, primarily concerned with terrorism and concluded in the 1970 s and 1980 s, ${ }^{181}$ have been understood by some to "create" universal jurisdiction over the crimes that are the subject matter of those treaties. ${ }^{182}$ It has been suggested that the terrorism treaties reflect a power of states to create, by treaty, extraterritorial jurisdiction having no other legal basis, and then to apply that jurisdiction to the nationals of non-party states. If the terrorism treaties can thus create jurisdiction that can be exercised over non-party nationals, the argument proceeds, then the ICC Treaty must be able to do the same. As will be demonstrated in the following pages, the terrorism treaties, if they "create" universal jurisdiction at all, do so by contributing to the development of customary law, not through some exceptional form of fiat by treaty. The terrorism treaties thus cannot be relied upon as precedents validating ICC jurisdiction over non-party nationals.

179. D'AmATO, supra note 170 , at 165.

180. Even if the ICC Treaty has not as yet generated customary law supporting ICC jurisdiction over non-party nationals, such custom could conceivably emerge in the future. If and when such a development should take place, the United States presumably would be in a position to claim persistent objector status with regard to ICC jurisdiction over its nationals, having clearly articulated its objections to the purported jurisdiction immediately and consistently from the time it was proposed. For analyses of the preconditions for and consequences of persistent objector status, see Jonathan Charney, Universal International Law, 87 AM. J. INT'L L. 529 (1993); David Colson, How Persistent Must the Persistent Objector Be?, 61 WASH. L. REV. 957 (1986).

181. See infra notes $183-190$ and accompanying text.

182. See, e.g., Scharf, supra note 68 , at 99-100. 
Treaties on hijacking ${ }^{183}$ and other crimes on aircraft, ${ }^{184}$ crimes against the safety of maritime navigation, ${ }^{185}$ hostage-taking, ${ }^{186}$ attacks on internationally protected persons ${ }^{187}$ and U.N. personnel, ${ }^{188}$ terrorist bombings, ${ }^{189}$ and torture,${ }^{190}$ each contains provisions permitting a state party to prosecute individuals believed to have committed the enumerated crimes when such individuals are found within its territory. As no link other than the presence of the suspect is required, jurisdiction would not be based on territoriality, nationality, protective principle, or passive personality but, rather, upon universality of jurisdiction. Because the crimes covered by the treaties in question arguably were not previously recognized as entailing universal jurisdiction, and yet the treaties provide that universal jurisdiction may be exercised over those crimes, the treaties, it is argued, must have created universal jurisdiction over those crimes.

But that conclusion must be incorrect. States are not obliged simply to accept purported new subjects of universal jurisdiction. In the absence of customary law recognizing universal jurisdiction over a given crime, each state may acquiesce in or protest against a proposed new subject of universal jurisdiction. In the event of a protest, the ensuing debate would invoke the usual criteria for determining the legitimacy of a new form of jurisdiction. ${ }^{191}$ Customary law governing the matter would then emerge accordingly. The terrorism treaties that some believe to create universal jurisdiction represent agreements by the states parties not to object when others (or, at least, other states parties) exercise jurisdiction as delineated by the treaties. But the treaties cannot bind non-parties also to accept the treaties' terms.

How, then, are we to understand the import of the treaties that do appear on their face to purport to create universal jurisdiction? Are they simply void, having exceeded the bounds of the customary international law of universal ju-

183. See Convention for the Suppression of Unlawful Seizure of Aircraft, Dec. 16, 1970, 22 U.S.T. 1641, 860 U.N.T.S. 105.

184. See Montreal Convention for the Suppression of Unlawful Acts Against the Safety of Civil Aviation, Sept. 23, 1971, 24 U.S.T. 564, 974 U.N.T.S. 177; Protocol for the Suppression of Unlawful Acts of Violence at Airports Serving International Civil Aviation, supplementary to the Convention of Sept. 23, 1971, Feb. 24, 1988, S. Treaty Doc. No. 100-19.

185. See Convention and Protocol on the Suppression of Unlawful Acts Against the Safety of Maritime Navigation, Mar. 10, 1988, 27 I.L.M. 668.

186. See International Convention Against the Taking of Hostages, Dec. 17, 1979, TIAS No. 11,081, 1316 U.N.T.S. 205.

187. See Convention on the Prevention and Punishment of Crimes Against Internationally Protected Persons, Including Diplomatic Agents, Dec. 14, 1973, 28 U.S.T. 1975, 1035 U.N.T.S. 167.

188. See Convention on the Safety of United Nations and Associated Personnel, Dec. 15, 1995, U.N. GAOR 49th Sess., Supp. No. 49, Vol. 1, at 299, U.N. Doc. A/49/49 (Jan. 9, 1994), 34 I.L.M. 482 (1995).

189. See International Convention for the Suppression of Terrorist Bombings, 37 I.L.M. 249 (1998).

190. See Convention Against Torture and Other Cruel, Inhuman or Degrading Treatment of Punishment, opened for signature Dec. 10, 1984, 23 I.L.M. 1027, 1465 U.N.T.S. 85. Torture is not a terrorism offense, but the Torture Convention's jurisdictional provisions fit within the mold of the provisions found in the terrorism conventions.

191. See supra text accompanying notes 124-144. 
risdiction? Some have taken that view. ${ }^{192}$ An alternative theory, however, would view the treaties as "proposing" the development of customary law.

The terrorism treaties that are cited as creating universal jurisdiction all concern crimes that already were, at the time of the treaties' conclusion, prime candidates for universal jurisdiction. Some of the crimes were already considered by some to entail universal jurisdiction. ${ }^{193}$ And even those that arguably did not yet entail universal jurisdiction shared the principal indicia of crimes over which universal jurisdiction is thought to be suitable. They were crimes of substantial seriousness, of concern to all states, and that are difficult to control without substantial international cooperation. ${ }^{194}$ What the treaties did was, in effect, to propose-to articulate ${ }^{195}$ in a clear form-the suggestion that the crimes become recognized as entailing universal jurisdiction. States were then free to respond to that proposal, by active acceptance (in becoming states parties to the treaties) or active rejection (by objecting to the treaties or to prosecutions brought pursuant to them) or passive acquiescence (by accepting, or refraining from objecting to, the treaties or prosecutions pursuant thereto). As D'Amato has put it,

[t] he articulation of a rule of international law-whether it be a new rule or a departure from and modification of an existing rule-in advance of or concurrently with a positive act (or omission) of a state gives a state notice that its action or decision will have legal implications. In other words, given such notice, statesmen will be able freely to decide whether or not to pursue various policies, knowing that their acts may create or modify international law. ${ }^{196}$

It appears that, as one might have predicted, the response to the jurisdictional provisions of the terrorism treaties has been acceptance and acquiescence. There have been a number of prosecutions under the terrorism treaties of individuals who were not nationals of states parties to those treaties, and yet there appears to be, thus far, no case in which the defendant's state of nationality has objected to that exercise of jurisdiction.

192. See, e.g., Jordan Paust, Extradition of the Achille-Lauro Hostage-Takers: Navigating the Hazards, 20 VANDERBILT J. TRANSNAT'L L. 235, 254 (1987) (“[u]niversal jurisdiction by treaty under the Hostages Convention ... is highly suspect with regard to defendants who are not nationals of a signatory to the Hostages Convention.").

193. See, e.g., RESTATEMENT (THIRD) OF THE FOREIGN RELATIONS LAW OF THE UNITED STATES $\S 404$ (1987); Kenneth C. Randall, Universal Jurisdiction Under International Law, 66 TEX. L. REV. 785, 834-38 (1988);

194. Michael Akehurst has made a similar observation:

Hijacking is probably not covered by the definition of piracy in international law, but there is doctrinal authority for the view that it is subject to universal jurisdiction nevertheless; Japan in fact claimed universal jurisdiction even before the Hague Convention. Hijacking threatens international communications to the same extent as piracy; it is an attack on international order and injures the international community as a whole, which means that all states have a legitimate interest in repressing it. The policy reasons which justify universal jurisdiction over piracy justify it equally in the case of hijacking.

Akehurst, supra note 129, at 161-62.

195. On the role of articulation in the development of customary international law, see D'AMATO, supra note 170 , at $74-87$.

196. Id at 75. 
In the Yunis case, ${ }^{197}$ for example, the United States prosecuted a Lebanese national under the United States' implementing legislation for the Convention for the Suppression of Unlawful Seizure of Aircraft ${ }^{198}$ and the International Convention Against the Taking of Hostages. ${ }^{199}$ Lebanon was a party to the former but not the latter convention. Nevertheless, Lebanon raised no objection to the prosecution of Yunis for hostage taking.

It is significant to note as well that the United States, in Yunis, did not take the position that the terrorism treaties themselves created universal jurisdiction. Rather the United States in its appellate brief argued that

the universal and passive personality theories of extraterritorial jurisdiction "together provide ample ground [ ] to assert jurisdiction over Yunis", [quoting the trial court's opinion in Yunis].

As that [trial court] decision explains, the universal theory recognizes that certain offenses are so heinous and widely condemned that "any state if it captures the offender may prosecute and punish that person on behalf of the world community regardless of the nationality of the offender or victim or where the crime was committed."

Both the offenses of the aircraft hijacking and hostage taking fall squarely within this principle. Air piracy has been condemned by the 143 nations that are signatories of the Hague Convention, a treaty that, as explained previously, expressly authorizes the prosecution on the basis of the universal principle. Hostage taking has been condemned by the international community in the International Convention Against the Taking of Hostages, which, likewise, recognizes the assertion of extraterritorial jurisdiction under the universal theory. Congress was, therefore, well within its authority to create extraterritorial criminal jursidiction over such universally condemned crimes.

The offense of hostage taking is also cognizable under the "passive personality" theory of jurisdiction which authorizes a state to assert jurisdiction over offenses commited against their citizens abroad.

United States v. Rezaq ${ }^{201}$ is the other case sometimes cited to demonstrate that the United States prosecutes nationals of states not parties to the terrorism treaties under legislation implementing those treaties. But Rezaq, a Palestinian, was not a national of a state whose treaty participation the United States would have recognized or whose diplomatic objection the United States would have recognized even if, contrary to the facts as they actually unfolded, an attempt had been made to lodge a protest against the exercise of jurisdiction over Rezaq. ${ }^{202}$ Because of those features of the Rezaq case, the fact that no state ob-

197. United States v. Yunis, 681 F. Supp. 896 (D.D.C. 1988); United States v. Yunis, 924 F. 2d 1086

(D.C. Cir. 1991).

198. Supra note 184.

199. Supra note 186.

200. Brief for the United States at 32-34, United States v. Yunis, 924 F.2d 1086 (D.C. Cir. 1991) (No. 89-3208).

201. United States v. Rezaq, 899 F. Supp. 697 (D.D.C. 1995); United States v. Rezaq, 134 F. $3 d 1121$ (D.C. Cir. 1998).

202. See Telephone Interview with Scott Glick, prosecuting attorney in United States v. Rezaq, U.S. Department of Justice, Terrorism Division, in Washington, DC, Sept. 15, 1999. A claim, by Rezaq, to Jordanian nationality would not have been helpful to his case. Jordan was a party to the hijacking convention pursuant to which Rezaq was prosecuted. See id. 
jected to the prosecution of Rezaq does little to clarify one way or the other the status of the terrorism treaties relative to the customary law of universal jurisdiction.

As of the time of this writing, there have been, to the author's knowledge, no diplomatic protests against the exercise of universal jurisdiction over the crimes that form the subject matter of the terrorism treaties. If that trend continues, then, with sufficient time and state practice, universal jurisdiction over these crimes will pass into customary law.

Through the catalyst of a treaty proposing a new application of universal jurisdiction, the usual processes of customary law development may be accelerated. This occurs not through any deviation from the usual principles governing the development of custom, but simply through an increased rate of occurrence of those actions (acceptance, acquiescence, expressions of opinio juris, and the like) through which customary law develops. ${ }^{203}$ The treaty itself does not "create" universal jurisdiction, and it could not do so insofar as that would involve the alteration of customary international law without the necessary processes of state practice and opinio juris. Rather, each of the treaties floats a clear proposal for response. If a non-party state were to object to the jurisdiction proposed or to its exercise (as has occurred in the case of the ICC Treaty), the validity of the jurisdiction would have to be evaluated in the usual way. A determination would have to be made as to whether the claimed new basis of

A similar circumstance arose in the case of Public Prosecutor v. S.H.T., a case prosecuted in the Netherlands pursuant to the Convention for the Suppression of Unlawful Seizure of Aircraft, supra note 183, and the Convention for the Suppression of Unlawful Acts against the Safety of Civil Aviation, supra note 184, in which the defendant "had been born in Jerusalem and was a resident of East Jerusalem.” Public Prosecutor v. S.H.T., 74 INT'L L. REPORTS 162, 163 (1987).

203. This approach to the meaning of the jurisdictional provisions of the terrorism treaties is reflected in Professor Schachter's reasoning. As he has written,

several multinational conventions dealing with crimes of international significance such as hijacking and sabotage of aircraft, hostage-taking, [and] injury to internationally protected persons ... oblige the parties to extradite or alternatively try and punish individuals accused of the crime covered by the convention. A significant feature is that the treaty obligation applies to all offenders apprehended by the state in question, whether the crime was committed in or outside of the state and whether or not it involved injury to nationals. An inference has been drawn from the fact that these conventions have been adopted and ratified by a large number of states that 'universal jurisdiction' applies to the crimes in question.... The reasoning here is that if a large number of states have agreed to the obligation to try and punish such offenses, the states must, as a matter of logic, have the right to exercise such jurisdiction under general (i.e., customary) international law. It follows that the right under customary law extends to all states, parties and non-parties....

To reach the conclusion that customary law allows for universal jurisdiction in regard to the crimes covered by the treaties, one has to rely on three conditions:

1) The adoption of the conventions by overwhelmingly large majorities of states;

2) The implication drawn from these conventions that international law permits states to exercise jurisdiction on a universal basis in regard to the crimes in question; and

3) The widespread ratification of the Conventions considered as relevant State practice that conforms to the implicit customary law principle stated in (2) above.

Schachter, supra note 170, at 725-26. 
jurisdiction comported with the principles underlying and defining the customary international law of jurisdiction.

The merits of this theory of the terrorism treaties as proposing the development of custom may be clarified by a contrasting example. Imagine that, rather than providing for universal jurisdiction over hijacking, hostage taking, and the like, the treaties had provided for universal jurisdiction over larceny. The larceny treaty or prosecutions brought pursuant thereto presumably would have been objected to promptly by states preferring to retain exclusive jurisdiction over larceny committed on their own territory when that larceny has no special link with other states. It is hard to imagine how the larceny treaty's universal jurisdiction provisions could be defended. Non-party states would readily prevail by showing that there is no support in customary law principles for the claimed jurisdiction and that treaties to which they are not parties cannot "create" otherwise baseless jurisdiction over crimes committed on their territories.

The difference between the hypothetical larceny treaty and the terrorism treaties is that the various forms of terrorism, if and to the extent that they were not already subject to universal jurisdiction at the time of the treaties' promulgation, were likely candidates for universal jurisdiction (meaning that such jurisdiction was likely to be accepted and become customary), while larceny is not. The crimes covered by the terrorism treaties are crimes of concern to all states regardless of where the offense is committed, and are crimes of the sort that would be difficult to control without substantial international cooperation. Ordinary larceny, by contrast, shares neither of those characteristics. For that reason, states would be unlikely to accept the universal jurisdiction proposed in the hypothetical larceny treaty even while states appear, thus far, to be willing to accept the universal jurisdiction proposed in the terrorism treaties.

To the extent that the terrorism treaties are viewed as proposing a new feature of customary law, subject to acceptance or rejection by non-parties, they are a potentially constructive contribution to international legal development. Viewed as an attempt simply to impose otherwise baseless jurisdiction over the nationals of non-party states without those states' consent, the treaties would simply be void.

The terrorism treaties do not represent any exceptional power to create universal jurisdiction by treaty or in any other exceptional way to alter the customary international law of jurisdiction. Rather, the terrorism treaties, properly viewed, are an example of the development of customary international law through the catalyst of treaty making. All that treaties can do, relative to the incorporation of new bases of jurisdiction into the customary law of jurisdiction, is to propose the desired innovation. Where the proposal is widely accepted, the jurisdictional innovation will pass into custom. The terrorism treaties appear to exemplify this process. The hypothetical treaty providing for universal jurisdiction over larceny is an example of a proposal that would be rejected and, consequently, would not generate custom. The ICC Treaty, and in particular its 
jurisdictional provisions, can do no more than to propose a jurisdictional innovation to be accepted or rejected by states.

\section{$\mathrm{V}$}

\section{CONCLUSION}

The ICC is intended to do an overwhelmingly important job. An international criminal court would, in many instances, be the only meaningful forum in which to pursue justice for crimes of the greatest enormity. The dilemma underlying the debate about ICC jurisdiction over non-party nationals stems primarily from the conflicting needs for the ICC to have sufficient jurisdictional powers to bring to justice perpetrators of genocide, war crimes, and crimes against humanity, and, simultaneously, for states to retain appropriate discretion regarding methods of dispute settlement when the lawfulness of their official acts is in dispute.

Given the terms of the ICC Treaty, the ICC would very likely engage in the compulsory adjudication of interstate disputes through the mechanism of criminal prosecutions, a prospect that many states will, and perhaps should, reject. Fundamental principles of international law reserve to states the right to resolve their disputes by such mechanisms as they find most suitable, limited by such obligations as they have agreed to by treaty or become bound to by custom. The resolution of interstate disputes by the ICC through the mechanism of criminal prosecutions is not a method that non-parties to the ICC Treaty have agreed by treaty to or become bound to by custom. Thus, the very treaty that would establish a new court to enforce international law may itself breach important international legal principles. Until this basic issue is confronted and satisfactorily resolved, the ICC and, in turn, the critical human interests that the court is intended to serve, will likely suffer from a damaging lack of participation. President Clinton's remarks, in his statement authorizing U.S. signature of the ICC Treaty, are telling in this regard. As he stated:

In signing, however, we are not abandoning our concerns about significant flaws in the treaty. In particular, we are concerned that when the court comes into existence, it will not only exercise authority over personnel of states that have ratified the treaty, but also claim jurisdiction over personnel of states that have not. ...

Court jurisdiction over U.S. personnel should come only with U.S. ratification of the treaty. The United States should have the chance to observe and assess the functioning of the Court, over time, before choosing to become subject to its jurisdiction. Given these concerns, I will not, and do not recommend that my successor submit the Treaty to the Senate for advice and consent until our fundamental concerns are satisfied. ${ }^{20}$

204. Associated Press, Clinton's Words: "The Right Action”, N.Y. TIMES, Jan. 1, 2001, at A6 (reprinting the text of President Clinton's statement authorizing U.S. signature of the ICC Treaty). 